\title{
Transactions
}

Cite this: DOI: 10.1039/c0dt01580f

wWW.rsc.org/dalton

PAPER

\section{Structural, spectroscopic and redox properties of uranyl complexes with a maleonitrile containing ligand $\dagger$}

\author{
Helen C. Hardwick, ${ }^{a}$ Drew S. Royal, ${ }^{a}$ Madeleine Helliwell, ${ }^{b}$ Simon J. A. Pope, ${ }^{c}$ Lorna Ashton, ${ }^{d}$ Roy Goodacre ${ }^{d}$ \\ and Clint A. Sharrad*a,e,f
}

Received 14th November 2010, Accepted 17th March 2011

DOI: 10.1039/c0dt01580f

The reaction of uranyl nitrate hexahydrate with the maleonitrile containing Schiff base 2,3-bis[(4-diethylamino-2-hydroxybenzylidene)amino]but-2-enedinitrile (salmnt ${ }^{\left(\mathrm{Et}_{2} \mathrm{~N}_{2}\right.} \mathrm{H}_{2}$ ) in methanol produces $\left[\mathrm{UO}_{2}\left(\right.\right.$ salmnt $\left.\left.{ }^{(\mathrm{E} 2 \mathrm{~N}) 2}\right)\left(\mathrm{H}_{2} \mathrm{O}\right)\right](\mathbf{1})$ where the uranyl equatorial coordination plane is completed by the $\mathrm{N}_{2} \mathrm{O}_{2}$ tetradentate cavity of the ( $\left(\mathrm{salmnt}^{\left(\mathrm{E}_{2} \mathrm{~N}_{2}\right.}\right)^{2-}$ ligand and a water molecule. The coordinated water molecule readily undergoes exchange with pyridine (py), dimethylsulfoxide (DMSO),

$N, N$-dimethylformamide (DMF) and triphenylphosphine oxide (TPPO) to give a series of $\left[\mathrm{UO}_{2}\left(\mathrm{salmnt}^{\left(\mathrm{Et}_{2} \mathrm{~N}_{2}\right)}\right)(\mathrm{L})\right]$ complexes $(\mathrm{L}=$ py, DMSO, DMF, TPPO; 2-5, respectively). X-Ray crystallography of 1-5 show that the (salmnt $\left.{ }^{\left(\mathrm{Et}_{2} \mathrm{~N} / 2\right.}\right)^{2-}$ ligand is distorted when coordinated to the uranyl moiety, in contrast to the planar structure observed for the free protonated ligand (salmnt ${ }^{\left(\mathrm{Et}_{2} \mathrm{~N}_{2}\right.} \mathrm{H}_{2}$ ). The Raman spectra of 1-5 only display extremely weak bands $\left(819-828 \mathrm{~cm}^{-1}\right)$ that can be assigned to the typically symmetric $\mathrm{O}=\mathrm{U}=\mathrm{O}$ stretch. This stretching mode is also observed in the infrared spectra for all complexes 1-5 $\left(818-826 \mathrm{~cm}^{-1}\right)$ predominantly caused by the distortion of the tetradentate $\left(\text { salmnt }{ }^{\left(\mathrm{Et}_{2} \mathrm{~N}_{2}\right.}\right)^{2-}$ ligand about the uranyl equatorial plane resulting in a change in dipole for this bond stretch. The solution behaviour of 2-5 was studied using NMR, electronic absorption and emission spectroscopy, and cyclic voltammetry. Complexes 2-5 exhibit intense absorptions in the visible region of the spectrum due to intramolecular charge transfer (ICT) transitions and the luminescence lifetimes $(<5 \mathrm{~ns})$ indicate the emission arises from ligand-centred excited states. Reversible redox processes assigned to the $\left\{\mathrm{UO}_{2}\right\}^{2+} /\left\{\mathrm{UO}_{2}\right\}^{+}$couple are observed for complexes $\mathbf{2 - 5}\left(\mathbf{2}: E_{1 / 2}=-1.80 \mathrm{~V} ; \mathbf{3 , 5}: E_{1 / 2}=\right.$ $-1.78 \mathrm{~V} ; 4: E_{1 / 2}=-1.81 \mathrm{~V}: v$ s. ferrocenium/ferrocene $\left.\left\{\mathrm{Fc}^{+} / \mathrm{Fc}\right\}, 0.1 \mathrm{M} \mathrm{Bu}_{4} \mathrm{NPF}_{6}\right)$ in dichloromethane (DCM). These are some of the most negative half potentials for the $\left\{\mathrm{UO}_{2}\right\}^{2+} /\left\{\mathrm{UO}_{2}\right\}^{+}$couple observed to date and indicate the strong electron donating nature of the $\left(\mathrm{salmnt}^{\left(\mathrm{Et}_{2} \mathrm{~N}_{2}\right.}\right)^{2-}$ ligand. Multiple uranyl redox processes are clearly seen for $\left[\mathrm{UO}_{2}\left(\operatorname{salmnt}{ }^{\left(\mathrm{Et}_{2} \mathrm{~N}\right)_{2}}\right)(\mathrm{L})\right]$ in $\mathrm{L}(\mathrm{L}=$ py, DMSO, DMF; 2-4: $0.1 \mathrm{M}$ $\mathrm{Bu}_{4} \mathrm{NPF}_{6}$ ) indicating the relative instability of these complexes when competing ligands are present, but the reversible $\left\{\mathrm{UO}_{2}\right\}^{2+} /\left\{\mathrm{UO}_{2}\right\}^{+}$couple for the intact complexes can still be assigned and shows the position of this couple can be modulated by the solvation environment. Several redox processes were also observed between +0.2 and $+1.2 \mathrm{~V}\left(v s\right.$. $\left.\mathrm{Fc}^{+} / \mathrm{Fc}\right)$ that prove the redox active nature of the maleonitrile-containing ligand.

${ }^{a}$ Centre for Radiochemistry Research, School of Chemistry, The University of Manchester, Oxford Road, Manchester, United Kingdom M13 9PL. E-mail: clint.a.sharrad@manchester.ac.uk; Fax:+44 161275 4598; Tel: +44 1612754657

${ }^{b}$ School of Chemistry, The University of Manchester, Oxford Road, Manchester, United Kingdom M13 9PL

'School of Chemistry, Main Building, Cardiff University, Park Place, Cardiff, United Kingdom CF10 3AT

${ }^{d}$ School of Chemistry, Manchester Interdisciplinary Biocentre, The University of Manchester, 131 Princess Street, Manchester, United Kingdom M1 $7 D N$

${ }^{e}$ School of Chemical Engineering and Analytical Science, The University of Manchester, Oxford Road, Manchester, United Kingdom M13 9PL

${ }^{f}$ Research Centre for Radwaste and Decommissioning, Dalton Nuclear Institute, The University of Manchester, Oxford Road, Manchester, United Kingdom M13 9PL

\section{Introduction}

The actinide elements are known to exhibit complex redox behaviour with oxidation states + III to + VI accessible in solution for uranium to americium. ${ }^{1}$ In the case of uranium, +VI is the dominant oxidation state in aerobic, aqueous solution and predominantly exists as the linear dioxo species, uranyl (i.e.

$\dagger$ Electronic supplementary information (ESI) available: X-ray crystallographic details (as CIF files) of salmnt ${ }_{2}^{(\mathrm{Et}}{ }_{2}{ }_{2} \mathrm{H}_{2} \cdot \mathrm{CH}_{2} \mathrm{Cl}_{2}, \mathbf{1} \cdot\left(\mathrm{CH}_{3} \mathrm{CH}_{2}\right)_{2} \mathrm{O}$ ), 2-4, 5. $\mathrm{H}_{2} \mathrm{O},\left[\mathrm{UO}_{2}\right.$ (salophen)(py)] and $\left[\mathrm{UO}_{2}\right.$ (salen)(TPPO)].TPPO. Selected NMR, Raman and electronic absorption spectroscopy data, and cyclic voltammetry data are presented. CCDC reference numbers 802704 802712. For ESI and crystallographic data in CIF or other electronic format see DOI: $10.1039 / \mathrm{c} 0 \mathrm{dt} 01580 \mathrm{f}$ 
$\left\{\mathrm{UO}_{2}\right\}^{2+}$ ). Low oxidation state uranium(III/IV) species can be obtained under inert atmospheric conditions, but are usually readily oxidised to the uranyl form in the presence of air. ${ }^{1}$ However, uranium(Iv) complexes have been known to form by photoreduction of the uranyl precursor under aerobic conditions. ${ }^{2}$ Uranyl(v) species have previously been extremely difficult to isolate due to the propensity for disproportionation to occur (i.e. " $2\left\{\mathrm{UO}_{2}\right\}^{+} \rightarrow \mathrm{U}^{4+}+\left\{\mathrm{UO}_{2}\right\}^{2+}$ "). ${ }^{3}$ Recently, it has been shown that uranyl(v) complexes can be obtained under stringently anhydrous conditions, either by controlled 2-electron oxidation of uranium(III), ${ }^{4}$ one-electron reduction of uranium(VI), ${ }^{5-10}$ or by ligand exchange with a $\left\{\mathrm{UO}_{2}\right\}^{+}$ precursor. $^{9}$

The influence of steric bulk and denticity of a ligand on the redox properties of actinyl complexes has been reasonably well studied. ${ }^{5-10}$ In contrast, the properties of actinyl complexes with redox active ligands are relatively unexplored. One reason for this is that in actinide complexes with certain redox active ligands, such as catecholate (Fig. 1), can be extremely difficult to characterise mainly due to the formation of insoluble bridged polymeric species. Raymond et al. have overcome this problem by using an excess of catecholate in highly alkaline conditions to give monometallic $\mathrm{Th}(\mathrm{IV}), \mathrm{U}(\mathrm{IV})$ and $\mathrm{Pu}(\mathrm{IV})$ complexes. ${ }^{11,12}$ They have also designed derivatives of catecholate that minimise the formation of polymetallic species. ${ }^{12,13}$ There are numerous examples of actinide complexes where the ligand redox activity has been explored, including the isolation of radical species, but these are generally limited to low valent actinide (i.e. III/IV) species with various redox active ligand moieties including pyridyl, porphyrin, diazoalkane and benzophenone groups. ${ }^{14}$ Other common redox active ligands include diaminomaleonitrile and dithiomaleonitrile (Fig. 1) which have well established non-innocent properties in d-transition metal complexes. ${ }^{15}$ The nucleophilic sites on these molecules allow the possibility of designing larger ligands containing redox active units. ${ }^{16,17}$

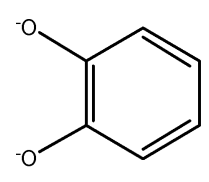

(a)

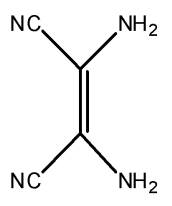

(b)

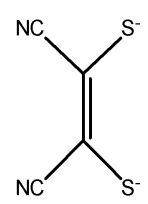

(c)
Fig. 1 Typical redox active ligands: (a) catecholate, (b) diaminomaleonitrile and (c) dithiomaleonitrile.

Tetradentate Schiff base ligands with an $\mathrm{N}_{2} \mathrm{O}_{2}$ donor set (Fig. 2), such as salen ${ }^{2-}\left(N, N^{\prime}\right.$-disalicylidene-1,2-ethylenediaminate) and salophen $^{2-} \quad\left(N, N^{\prime}\right.$-disalicylidene-1,2-phenylenediaminate $)$ are known to be effective chelators for the uranyl unit by coordination through the uranyl equatorial plane. ${ }^{5,18}$ The uranyl coordination sphere is usually completed by a monodentate ligand resulting

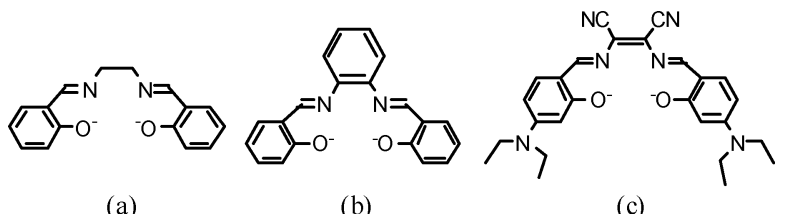

(a)

(b)

(c)

Fig. 2 Tetradentate Schiff base ligands: (a) salen ${ }^{2-}$, (b) salophen ${ }^{2-}$ and (c) $\left(\operatorname{salmnt}^{\left(\mathrm{Et} 2 \mathrm{~N}_{2}\right.}\right)^{2-}$. in a pentagonal bipyramidal geometry about the uranium centre. Ikeda et al. have demonstrated that uranyl complexes of the Schiff base (salophen) $)^{2-}$ (i.e. $\left[\mathrm{UO}_{2}\right.$ (salophen)(DMSO)] and $\left[\mathrm{UO}_{2}\right.$ (salophen)(DMF)]) can be electrolytically reduced to form $\left\{\mathrm{UO}_{2}\right\}^{+}$complexes. ${ }^{5}$ Mazzanti et al. have shown that $\left\{\mathrm{UO}_{2}\right\}^{+}$ complexes of tetradentate Schiff base ligands, and derivatives thereof, of sufficient stability can be obtained to allow solid and solution state characterisation. ${ }^{9}$

We have synthesised a series of uranyl complexes with the ligand 2,3-bis[(4-diethylamino-2-hydroxobenzylidene)amino]but2-enedinitrile (Fig. 2), abbreviated as (salmnt $\left.{ }^{\left(\mathrm{Et}_{2} \mathrm{~N}\right)_{2}}\right)^{2-}$, and investigated their structural, spectroscopic and electrochemical properties. The ligand combines the effective uranyl-chelating properties of the planar tetradentate binding cavity with the redox active characteristics of the maleonitrile unit, providing an opportunity to probe the electrochemical behaviour of uranyl complexes with potentially non-innocent ligands. The protonated free ligand salmnt ${ }^{\left(\mathrm{E}_{2} \mathrm{~N}_{2}\right.} \mathrm{H}_{2}$ and its first row d-transition metal complexes have been previously studied for their non-linear optical properties and their potential application as organic light-emitting diodes. ${ }^{19,20}$ This is due to the highly conjugated nature of the ligand, which provides an intensely absorbing chromophore in the visible region of the electronic spectrum. However, the electrochemical behaviour of salmnt ${ }^{\left(\mathrm{Et}_{2} \mathrm{~N}_{2}\right.} \mathrm{H}_{2}$ and any subsequent complexes has yet to be explored. We have studied a series of uranyl complexes with (salmnt $\left.{ }^{\left(\mathrm{E}_{2} \mathrm{~N}_{2}\right.}\right)^{2-}$ by altering the monodentate ligand that completes the uranyl coordination sphere (Fig. 3) and probed how these changes affect the chemical and physical properties of these systems.

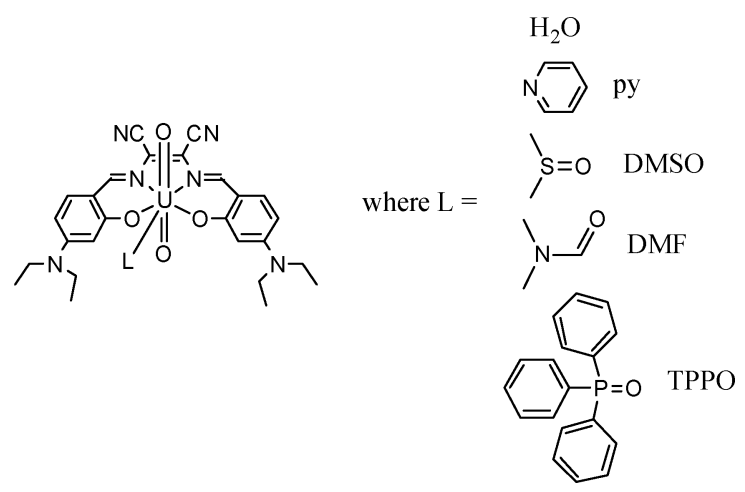

Fig. 3 Structural diagram of $\left[\mathrm{UO}_{2}\left(\operatorname{salmnt}^{\left(\mathrm{Et}_{2} \mathrm{~N}\right)}\right)(\mathrm{L})\right]$.

\section{Results and discussion}

\section{Synthesis and NMR spectroscopy}

The complexation of (salmnt $\left.{ }^{\left(\mathrm{Et}_{2} \mathrm{~N}_{2}\right.}\right)^{2-}$ to uranyl proceeded effectively when using the protonated form of the ligand mixed with uranyl nitrate hexahydrate in methanol and heating for several hours. Deprotonation of the phenols by an alkali before reacting with uranyl was not found to be necessary in order for complexation to proceed. A dark purple-black precipitate was obtained upon cooling the reaction mixture overnight, which can

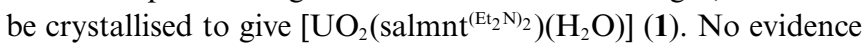
for the formation of the equivalent complex with a coordinating methanol molecule replacing the bound water was obtained. 
Performing the same reaction in different solvents (e.g. ethanol and acetonitrile) and different reaction times resulted in a mixture of products which proved to be very difficult to purify. ${ }^{1} \mathrm{H}$ NMR spectroscopy of recrystallised complex 1 in $\mathrm{d}_{2}$-DCM shows decomposition of the complex in solution with the small but significant presence of free salmnt ${ }^{\left(\mathrm{Et}_{2} \mathrm{~N}_{2}\right.} \mathrm{H}_{2}$. Extremely broadened resonances that can be assigned to complex $\mathbf{1}$ are observed but clearly indicate exchange processes occurring in solution which probably involves the removal of the monodentate water ligand and/or the removal of the entire (salmnt $\left.{ }^{\left(\mathrm{Et}_{2} \mathrm{~N} / 2\right.}\right)^{2-}$ ligand from complex $\mathbf{1}$, with the formation of intermediate species likely to arise.

The crude precipitate of $\mathbf{1}$ was readily dissolved in the coordinating solvents, py, DMSO and DMF, giving uranyl complexes (2-4) where the bound water was exchanged with the solvent. The exchange of the coordinated water of $\mathbf{1}$ can also be achieved in dichloromethane using an excess of a dissolved monodentate ligand, such as triphenylphosphine oxide (TPPO) to give complex 5. Attempts to form bimetallic systems similar to $\left[\mathrm{UO}_{2} \text { (salophen) }\right]_{2}$ where the monodentate ligand is removed and one of the phenolate groups on each ligand bridges to the adjacent uranyl unit, ${ }^{21}$ were unsuccessful.

The ${ }^{13} \mathrm{C}$ and ${ }^{1} \mathrm{H}$ NMR spectra complexes $\mathbf{2}-\mathbf{5}$ in $\mathrm{d}_{2}$-DCM (ESI D $^{\dagger}$ ) show the expected $\mathrm{C}_{2}$ symmetry with six ${ }^{1} \mathrm{H}$ and eleven ${ }^{13} \mathrm{C}$ NMR signals attributed to the (salmnt $\left.{ }^{\left(\mathrm{Et}_{2} \mathrm{~N}_{2}\right.}\right)^{2-}$ ligand. The resonances in these spectra for the py and DMF ligands in complexes $\mathbf{2}$ and $\mathbf{4}$, respectively, at room temperature are broadened suggesting that the monodentate ligand in these species undergoes exchange and/or rotation about the coordination bond with uranium on the NMR timescale. No evidence for the presence of free salmnt ${ }^{\left(\mathrm{Et}_{2} \mathrm{~N}_{2}\right.} \mathrm{H}_{2}$ was observed under these conditions indicating that the exchange processes observed in these examples do not ultimately result in decomposition of the complex. NMR spectra of complexes $\mathbf{2}$, 3 and $\mathbf{4}$ in $\mathrm{d}_{5}$-py, $\mathrm{d}_{6}$-DMSO and $\mathrm{d}_{7}$-DMF, respectively, at room temperature (ESI $\dagger$ ) show complex decomposition does not occur in the presence of these coordinating solvents with no ligand exchange processes at the NMR timescale observed.

\section{Vibrational spectroscopy}

Selected vibrational spectroscopic data are presented in Table 1. The infrared and Raman spectra of salmnt ${ }^{\left(\mathrm{Et}_{2} \mathrm{~N}_{2}\right.} \mathrm{H}_{2}$ exhibit bands at frequencies that are typical for $\mathrm{C} \equiv \mathrm{N}$ and $\mathrm{C}=\mathrm{N}$ bonds. Upon coordination to uranyl, the $\mathrm{C}=\mathrm{N}$ stretch shifts (i.e. 9-21 $\mathrm{cm}^{-1}$ ) to a lower frequency compared to the protonated free ligand. The infrared active $\mathrm{C}=\mathrm{N}$ stretch for complexes 1-5 falls in the range of $1601-1613 \mathrm{~cm}^{-1}$. A similar trend is observed in $\left\{\mathrm{UO}_{2}\right\}^{2+}$ and other metal complexes of tetradentate Schiff base ligands (e.g. salophen ${ }^{2-}$ and salen $^{2-}$ ). The $\mathrm{C} \equiv \mathrm{N}$ stretch does not shift significantly between the complexed and uncomplexed forms in the solid state. Little difference is observed in the position of the $\mathrm{C} \equiv \mathrm{N}$ stretch amongst the uranyl complexes $\mathbf{1 - 5}$ where the monodentate ligand is varied and, similarly, little change in the $\mathrm{C} \equiv \mathrm{N}$ stretch is observed between the uranyl and d-transition metal complexes of $\left(\text { salmnt }^{\left(\mathrm{Et}_{2} \mathrm{~N}_{2}\right.}\right)^{2-}$. These observations suggest that there is no variation in the intermolecular interactions in the solid state involving the peripheral cyano groups between uncomplexed and complexed forms of the (salmnt $\left.t^{\left(\mathrm{Et}_{2} \mathrm{~N}_{2}\right.}\right)^{2-}$ unit, irrespective of the complexing metal ion. It also indicates that there is little change in the charge distribution of the $\pi$-electronic structure between the protonated free ligand, d-transition metal complexes and uranyl complexes of ( $\left(\mathrm{salmnt}^{\left(\mathrm{Et}_{2} \mathrm{~N} / 2\right.}\right)^{2-} \cdot{ }^{29}$

The asymmetric uranyl stretch, $v_{3}$, observed in the infrared spectra of complexes 1-5 fall in the range of $885-899 \mathrm{~cm}^{-1}$ and are typical of uranyl complexes with tetradentate Schiff bases. ${ }^{5,22,23}$ Changing the monodentate equatorial ligand in these complexes has minimal influence on the strength of the $\mathrm{U}=\mathrm{O}$ bond. The Raman spectra for the uranyl complexes 1-5 (ESI $\dagger$ ) only show bands of extremely weak intensity between 819 and $828 \mathrm{~cm}^{-1}$ that can be attributed to the $v_{1}(\mathrm{O}=\mathrm{U}=\mathrm{O})$ stretching mode (Table 2). Altering the laser excitation frequency used to obtain the Raman spectra of these complexes from $1064 \mathrm{~nm}$ to $785 \mathrm{~nm}$ does not make any significant difference to the spectral profiles of complexes 1-5 (ESI $\dagger$ ). Sample fluorescence was only observed when attempting to obtain the Raman spectrum of salmnt ${ }^{\left(\mathrm{Et}_{2} \mathrm{~N}_{2}\right.} \mathrm{H}_{2}$ using an excitation wavelength of $785 \mathrm{~nm}$. The $v_{1}(\mathrm{O}=\mathrm{U}=\mathrm{O})$ stretch is also observed in the infrared spectra of $\mathbf{1 - 5}$ (Table 2) indicating that there is a change in the dipole moment for this stretching mode. Similar observations have been made for various uranyl salts and could suggest that the $\left\{\mathrm{UO}_{2}\right\}^{2+}$ moiety is non-linear in these examples. ${ }^{24}$ However, structural evidence (see Structure section) shows the $\mathrm{O}=\mathrm{U}=\mathrm{O}$ angle does not deviate substantially from $180^{\circ}$ and each pair of $\mathrm{U}=\mathrm{O}$ distances are similar for all complexes. The structures of 1-5 show the ligand to be in a distorted "stepped" conformation which lowers the overall symmetry of each complex in the solid state (see Structure section). The $v_{1}(\mathrm{O}=\mathrm{U}=\mathrm{O})$ stretch for all $\left[\mathrm{UO}_{2}\right.$ (salophen)(L)] (L = py, DMSO, DMF, TPPO) complexes in the solid state is also seen to be infrared allowed (Table 1). The salophen ${ }^{2-}$ ligand in these complexes adopts a conformation where the bridging 1,2-phenylenediamine unit clearly lies to one side of the uranyl equatorial plane (see Structure section). For $\left[\mathrm{UO}_{2}(\right.$ salen $\left.)(\mathrm{L})\right]$ complexes, the $v_{1}(\mathrm{O}=\mathrm{U}=\mathrm{O})$ stretch is observed, with very weak intensity, in the infrared spectrum when the monodentate ligand $\mathrm{L}$ does not predominantly lie in the uranyl equatorial plane (i.e. py, TPPO). The infrared spectra of $\left[\mathrm{UO}_{2}\right.$ (salen)(DMSO)] and $\left[\mathrm{UO}_{2}(\mathrm{salen})(\mathrm{DMF})\right]$, where the monodentate ligand is mostly found in the uranyl equatorial plane, do not exhibit the $v_{1}(\mathrm{O}=\mathrm{U}=\mathrm{O})$ stretch. Therefore, the $v_{1}$ $(\mathrm{O}=\mathrm{U}=\mathrm{O})$ stretch is infrared allowed for $\mathbf{1}-\mathbf{5}$ due to the lowering of the complex symmetry.

The $v_{1}(\mathrm{O}=\mathrm{U}=\mathrm{O})$ stretch is clearly observed in the Raman spectra of $\left[\mathrm{UO}_{2}(\right.$ salen $\left.)(\mathrm{L})\right]$ and $\left[\mathrm{UO}_{2}(\right.$ salophen)(L)] complexes, but is effectively Raman forbidden for 1-5. Hence, the presumably minimal change in polarizability that occurs with the $v_{1}$ $(\mathrm{O}=\mathrm{U}=\mathrm{O})$ stretch for $\mathbf{1}-\mathbf{5}$ is not caused by a simple lowering of the complex symmetry but the nature of the distortion caused by the (salmnt $\left.{ }^{\left(\mathrm{Et}_{2} \mathrm{~N} / 2\right.}\right)^{2-}$ ligand (see Structure section).

\section{Electronic spectroscopy}

The electronic absorption spectra of salmnt ${ }^{\left(\mathrm{Et}_{2} \mathrm{~N}_{2}\right.} \mathrm{H}_{2}$ and complexes 2-5 in dichloromethane (Fig. 4) show intense absorption bands $\left(\varepsilon_{\max }=10000-100000 \mathrm{~L} \mathrm{~mol}^{-1} \mathrm{~cm}^{-1}\right)$ from intramolecular charge transfer (ICT) transitions, due to the conjugated nature of the (salmnt $\left.{ }^{\left(\mathrm{Et}_{2} \mathrm{~N}_{2}\right.}\right)^{2-}$ unit. The unbound, protonated form of the ligand, salmnt ${ }^{\left(\mathrm{Et}_{2} \mathrm{~N}_{2}\right.} \mathrm{H}_{2}$, in dichloromethane gives a red-pink coloured solution with relatively sharp absorptions at 568, 436 and $378 \mathrm{~nm}$. A shoulder on the highest intensity absorption band 
Table 1 Selected bond stretching frequencies

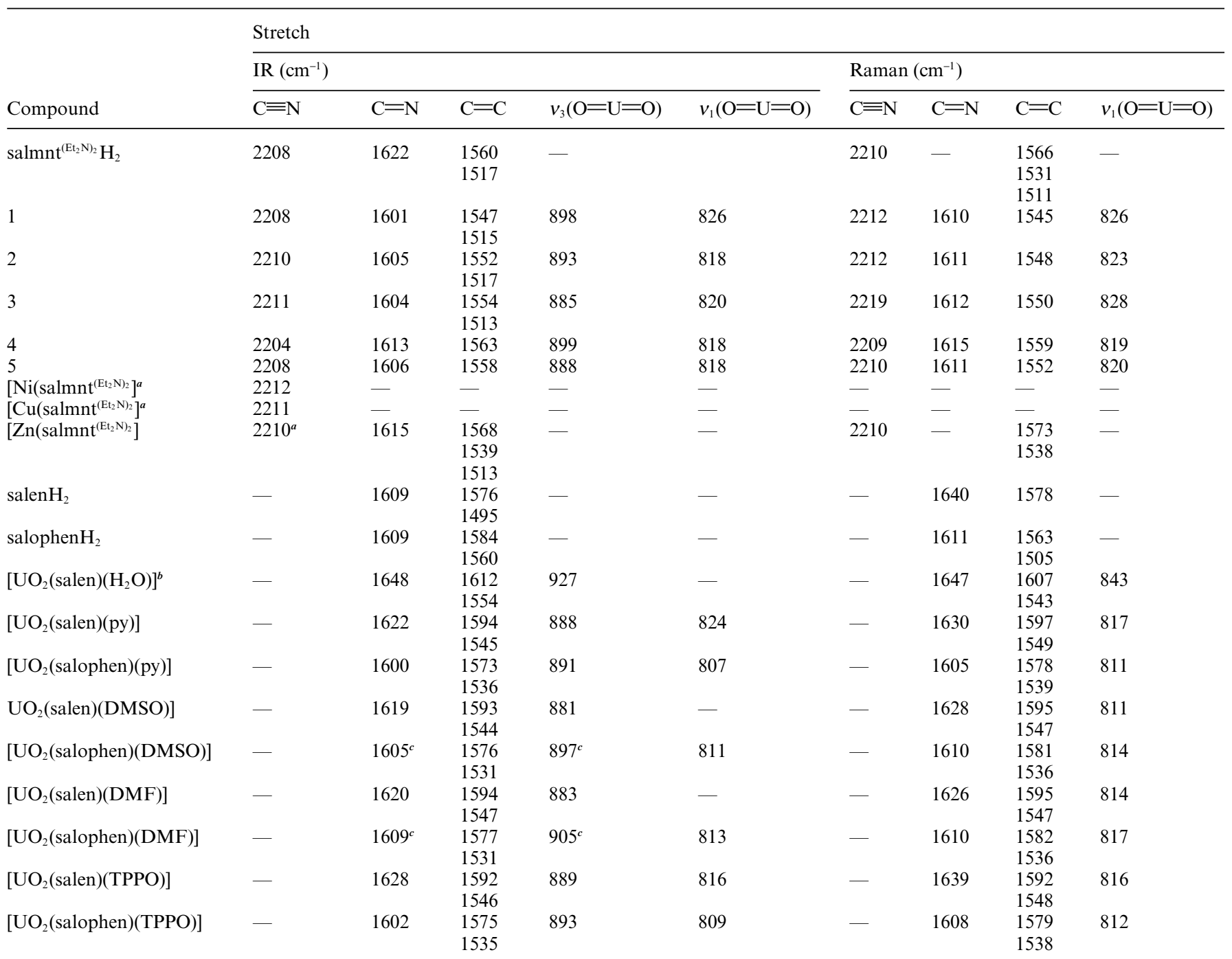

${ }^{a}$ Reference 19 Only $\mathrm{C} \equiv \mathrm{N}$ stretch reported. ${ }^{b}$ Reference $22 .{ }^{c}$ Reference 5.

Table 2 Selected interatomic distances (Å) for salmnt $t^{\left(\mathrm{Et}_{2} \mathrm{~N}_{2}\right.} \mathrm{H}_{2} \cdot \mathrm{DCM}$

\begin{tabular}{ll}
\hline $\mathrm{O}(2)-\mathrm{C}(18)$ & $1.353(6)$ \\
$\mathrm{O}(1)-\mathrm{C}(7)$ & $1.351(6)$ \\
$\mathrm{N}(5)-\mathrm{C}(16)$ & $1.306(6)$ \\
$\mathrm{N}(5)-\mathrm{C}(14)$ & $1.386(6)$ \\
$\mathrm{N}(2)-\mathrm{C}(11)$ & $1.308(7)$ \\
$\mathrm{N}(2)-\mathrm{C}(12)$ & $1.369(6)$ \\
$\mathrm{C}(13)-\mathrm{N}(3)$ & $1.146(7)$ \\
$\mathrm{C}(15)-\mathrm{N}(4)$ & $1.147(7)$ \\
$\mathrm{N}(2)-\mathrm{H}(1)$ & $1.941(4)$ \\
$\mathrm{N}(5)-\mathrm{H}(2)$ & $1.852(4)$ \\
\hline
\end{tabular}

$\left(\lambda_{\max }=568 \mathrm{~nm}\right)$ is found at $\sim 527 \mathrm{~nm}$ (Fig. 4). The uranyl complexes of (salmnt $\left.{ }^{\left(\mathrm{Et}_{2} \mathrm{~N}\right)_{2}}\right)^{2-}$ exhibit similar spectral profiles to that of salmnt ${ }^{\left(\mathrm{Et}_{2} \mathrm{~N}_{2}\right.} \mathrm{H}_{2}$ (Fig. 3), but the lowest energy transition (568 nm for salmnt ${ }^{\left(\mathrm{Et}_{2} \mathrm{~N}\right)_{2}} \mathrm{H}_{2}$ ) red-shifts upon uranyl complexation to a range between 574 and $584 \mathrm{~nm}$ (ESI $\dagger$ ) producing deep bluepurple coloured solutions. A similar red-shift is observed for this transition from the free ligand to d-transition metal complexes of $\left(\text { salmnt }^{\left(\mathrm{Et}_{2} \mathrm{~N}_{2}\right.}\right)^{2-} .{ }^{29}$ The higher energy transitions (436 and $378 \mathrm{~nm}$

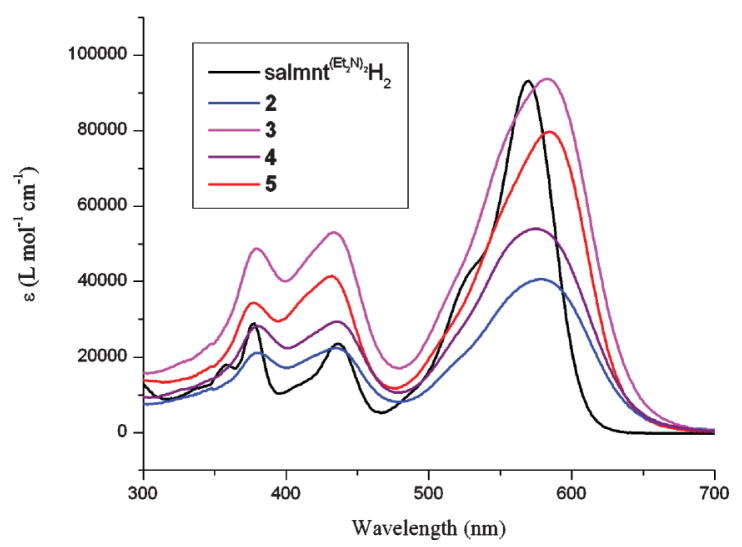

Fig. 4 Electronic absorption spectra for complexes 2-5 in DCM.

for salmnt ${ }^{\left(\mathrm{Et}_{2} \mathrm{~N}\right)_{2}} \mathrm{H}_{2}$ ) do not significantly shift between the free ligand and the uranyl complexes (ESI $\dagger$ ). However, all electronic absorption bands for uranyl complexes 2-5 are substantially 
broader compared to those of the protonated neutral ligand (Fig. 4). This broadening is not observed in the absorption spectra of [Ni(salmnt $\left.\left.{ }^{\left(\mathrm{Et}_{2} \mathrm{~N}_{2}\right.}\right)\right]$ in chloroform and [Cu(salmnt $\left.\left.{ }^{\left(\mathrm{Et}_{2} \mathrm{~N} / 2\right.}\right)\right]$ in acetonitrile. ${ }^{19}$ This is probably because of the higher number of vibrational sublevels in both the ground and excited states of the uranyl complexes compared to the free ligand and d-transition metal complexes, predominantly due to the coordination of a linear dioxo unit as opposed to the protonation of the phenolic oxygens or the coordination of a "naked" metal ion. Reports of related salophen-uranyl complexes suggest the possibility of ligand-to-metal charge transfer (LMCT) absorptions between 350 and $450 \mathrm{~nm}$ arising from phenolate-to- $\mathrm{U}(\mathrm{vI})$ electron transfer. ${ }^{25}$ Here, comparison with the spectrum of the protonated free ligand suggests that these transitions will not only overlap with IL (intraligand) absorptions, but also obscure any uranyl-centred oxide-to-U(VI) LMCT absorptions, which also occur in this region of the spectrum. ${ }^{25}$ These typically have very low extinction coefficients $\left.\left(\varepsilon<10 \mathrm{M}^{-1} \mathrm{~cm}^{-1}\right)\right)^{25}$

In dichloromethane solution at room temperature the luminescence spectra of the uranyl complexes were dominated by an intense emission at $c a$. $620 \mathrm{~nm}$ (following excitation at either 355 or $565 \mathrm{~nm}$ ). This contrasts with the closely related $\left[\mathrm{UO}_{2}\right.$ (salophen)(EtOH)] complex, which is not luminescent in $\mathrm{CHCl}_{3}$ under ambient conditions: this was attributed to lower-lying non-emissive LMCT arising from ligand-U(VI) interactions. ${ }^{25}$ Comparison with the protonated neutral ligand $\left(\lambda_{\mathrm{em}}=610 \mathrm{~nm}\right)$ suggests the emission arises from a ligand-centred CT (charge transfer) excited state, which is subtly modulated by the presence of the uranyl unit. These observations also suggest that the ILCT emitting state lies below any LMCT excited states. Timeresolved luminescence lifetime measurements on dichloromethane solutions were obtained from single-exponential data fits $\left(\lambda_{\mathrm{ex}}=\right.$ $459 \mathrm{~nm}$ ) and confirmed the nature of the emission as a fluorescence, where typical values for the uranyl complexes were $<5 \mathrm{~ns}$, which are comparable to the free protonated ligand. Despite the presence of the heavy $\mathrm{U}$ atom, no evidence was obtained for the observation of phosphorescence at longer wavelengths ([Au(salen)] possesses observable phosphorescence) ${ }^{26}$ With these complexes it was not possible, with solutions of $10^{-6} \mathrm{M}$, to detect emission that could be attributed to longer-lived, uranyl-centred LMCT, suggesting that any uranyl-centred excited states may be quenched by the ligand-based absorption bands throughout the visible region (350$525 \mathrm{~nm}$ ). Although the presence of coordinated solvent did not induce large shifts in the ligand-centred fluorescence, the profiles of each of the excitation spectra were subtly different.

\section{Structure}

The structure of salmnt ${ }^{\left(\mathrm{Et}_{2} \mathrm{~N}_{2}\right.} \mathrm{H}_{2} \cdot \mathrm{CH}_{2} \mathrm{Cl}_{2}$ (Fig. 5) clearly shows that the protonated form of the ligand is planar, mediated by a combination of hydrogen bonding between the phenol hydrogens and the adjacent imines, and the rigidity of the maleonitrile unit. The interatomic distances (Table 2) between the phenolic hydrogens and the adjacent imine nitrogens average $\sim 1.90 \AA$, which is typical of hydrogen bonding. The structure undoubtedly illustrates

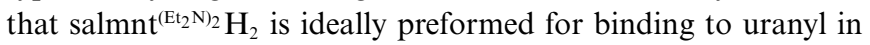
the equatorial plane by minimizing any entropic barriers. The only significant thermodynamic barrier for uranyl complexation is enthalpic with the deprotonation of the hydrogen bonded

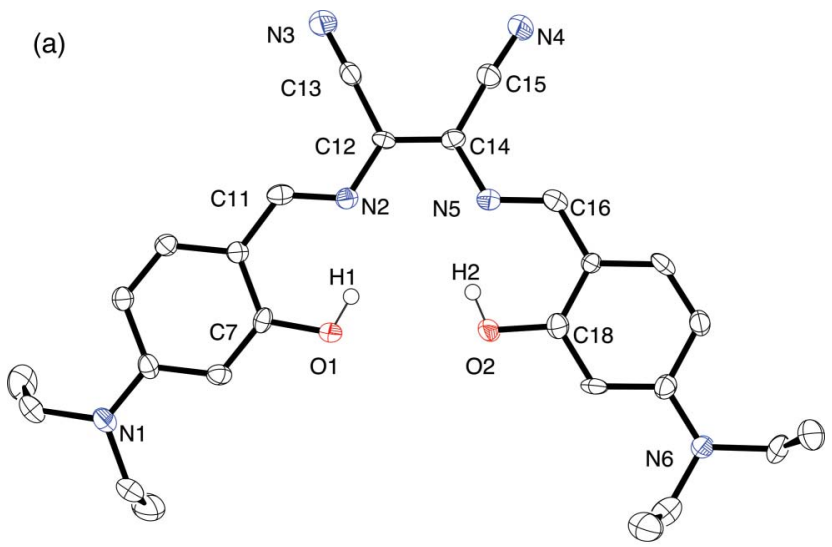

(b)

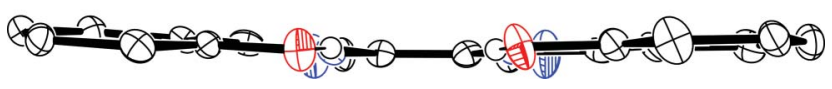

Fig. 5 ORTEP plots of salmnt ${ }^{\left(\mathrm{Et}_{2} \mathrm{~N}_{2}\right.} \mathrm{H}_{2} \cdot \mathrm{DCM}$ (DCM and all hydrogens omitted, except phenol hydrogens): (a) view orthogonal to the molecular $\mathrm{C}_{2}$ axis (with crystallographic numbering), (b) view along the molecular $\mathrm{C}_{2}$ axis $\left(\mathrm{Et}_{2} \mathrm{~N}\right.$ groups omitted for clarity).

phenols moiety required in order for metal binding to occur in the tetradentate $\mathrm{N}_{2} \mathrm{O}_{2}$ cavity.

The structure of 1. $\left(\mathrm{CH}_{3} \mathrm{CH}_{2}\right)_{2} \mathrm{O}$ (Fig. 6) shows the uranyl coordinated to the tetradentate $\mathrm{N}_{2} \mathrm{O}_{2}$ cavity of the (salmnt $\left.{ }^{\left(\mathrm{Et}_{2} \mathrm{~N}_{2}\right.}\right)^{2-}$ ligand. A water molecule is also coordinated to the uranyl unit forming a five coordinate environment about the uranyl equatorial plane in a slightly distorted pentagonal bipyramidal geometry about the uranium centre. The $\mathrm{U}=\mathrm{O}$ bond distances $(1.780(4) \AA)$

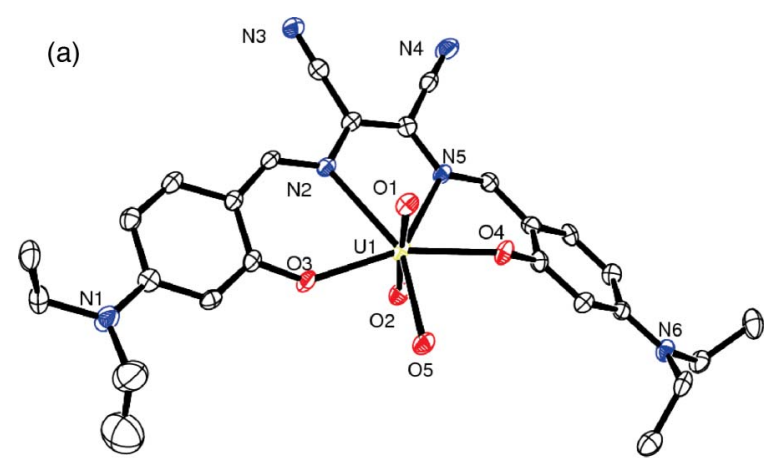

(b)

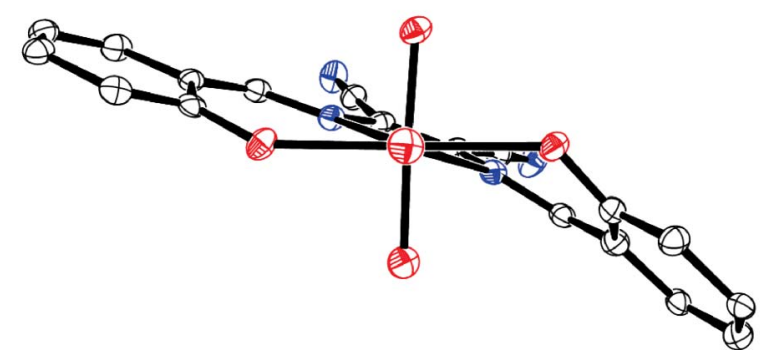

Fig. 6 ORTEP plots of the complex molecule of 1 (hydrogens omitted): (a) view near orthogonal to molecular $\mathrm{C}_{2}$ axis (with crystallographic numbering), (b) view along molecular $\mathrm{C}_{2}$ axis $\left(\mathrm{Et}_{2} \mathrm{~N}\right.$ groups omitted for clarity). 
and $\mathrm{O}=\mathrm{U}=\mathrm{O}$ angle $\left(177.46(17)^{\circ}\right)$ in $\mathbf{1} \cdot\left(\mathrm{CH}_{3} \mathrm{CH}_{2}\right)_{2} \mathrm{O}$ are typical for most uranyl complexes. ${ }^{27}$ The $\mathrm{U}-\mathrm{O}$ and $\mathrm{U}-\mathrm{N}$ distances for 1. $\left(\mathrm{CH}_{3} \mathrm{CH}_{2}\right)_{2} \mathrm{O}$ (Table 3) fall within the typical ranges for monometallic uranyl complexes with tetradentate Schiff base ligands (U-O: $2.20-2.33 \AA$; U-N: $2.51-2.65 \AA$ )..$^{28,29}$ The view along the $\mathrm{C}_{2}$ axis (Fig. 6(b)) shows that the ligand has distorted from the ideal planar geometry of the unbound protonated form. The phenolate oxygens are effectively positioned in the uranyl equatorial plane, evident by the angles between the oxo atoms $(\mathrm{O}(1)$ and $\mathrm{O}(2))$, the uranium centre $(\mathrm{U}(1)$ and the phenolate oxygens $(\mathrm{O}(3)$ and $\mathrm{O}(4))$ falling within a narrow range about $90^{\circ}$ (86-94 ${ }^{\circ}$, Table 3). This is due to the phenolate rings being able to move away from the normal plane of the $\left(\mathrm{salmnt}^{\left(\mathrm{Et}_{2} \mathrm{~N} / 2\right.}\right)^{2-}$ ligand by rotation about the imine carbon bond. The maleonitrile unit retains its planar geometry upon uranyl coordination resulting in the bound nitrogens being positioned significantly away from the uranyl equatorial plane. The departure of the angles between the coordinated nitrogens and the uranyl moiety away from $90^{\circ}$ can be used to indicate the extent of this distortion (i.e. $\mathrm{O}(1)-\mathrm{U}(1)-$ $\mathrm{N}(2)=81.72(16)^{\circ}, \mathrm{O}(1)-\mathrm{U}(1)-\mathrm{N}(5)=97.15(16)^{\circ}, \mathrm{O}(2)-\mathrm{U}(1)-$ $\left.\mathrm{N}(2)=100.24(15)^{\circ}, \mathrm{O}(2)-\mathrm{U}(1)-\mathrm{N}(5)=82.26(16)^{\circ}\right)$. The Schiff base ligands, salophen ${ }^{2-}$ and salen ${ }^{2-}$, can exhibit enough flexibility in their structure such that their donor atoms can be positioned relatively close to the equatorial plane when coordinated to the linear dioxo uranyl cation. ${ }^{28}$ The salophen ${ }^{2-}$ ligand adopts a "boat" structure where the central phenylenediamine linking unit is positioned on the opposite side of the uranyl equatorial plane to the salicylidene units, while salen ${ }^{2-}$ has a "stepped" conformation when bound to uranyl where the salicylidene units are at opposite sides of the equatorial plane with the "step" imparted by the flexible ethylenediamine unit. ${ }^{28}$ These conformations are displayed for $\left[\mathrm{UO}_{2}\left(\right.\right.$ salophen)(py)] and $\left[\mathrm{UO}_{2}(\right.$ salen)(TPPO)] exhibiting the "boat" and "stepped" structures, respectively (Fig. 7 and Table 4 - see ESI for views with crystallographic numbering $\dagger$ ). The conformation of the $\left(\mathrm{salmnt}^{\left(\mathrm{Et}_{2} \mathrm{~N}_{2}\right.}\right)^{2-}$ ligand in complex 1 most closely resembles that of the "stepped" conformation, but is distorted due to the rigidity of the maleonitrile group. Similar structural characteristics are seen for all the $\left[\mathrm{UO}_{2}\left(\operatorname{salmnt}^{\left(\mathrm{E}_{2} \mathrm{~N}_{2}\right.}\right)(\mathrm{L})\right]$ complexes 1-5 (Fig. 6, 8-11 and Table 3). The "stepped" conformation may preclude the formation of phenolate bridged bis(uranyl) complexes as for $\left[\mathrm{UO}_{2} \text { (salophen) }\right]_{2}$, where the salophen ligands adopt the "boat" conformation, and this is the only example of such a complex isolated to date. ${ }^{21}$ Attempts to form the analogous $\left[\mathrm{UO}_{2}\left(\operatorname{salmnt}^{\left(\mathrm{Et}_{2} \mathrm{~N}_{2}\right.}\right)\right]_{2}$ complex were unsuccessful. Similar distortions of the coordinating nitrogens away from the uranyl equatorial plane, indicated by the angles between the coordinated nitrogens and the uranyl moiety, are observed in the "stepped" conformation exhibited by $\left[\mathrm{UO}_{2}(\mathrm{salen})(\mathrm{TPPO})\right]$ $\left(\mathrm{O}(1)-\mathrm{U}(1)-\mathrm{N}(1)=80.3(2)^{\circ}, \mathrm{O}(1)-\mathrm{U}(1)-\mathrm{N}(2)=99.2(2)^{\circ}, \mathrm{O}(2)-\right.$ $\left.\mathrm{U}(1)-\mathrm{N}(1)=98.4(2)^{\circ}, \mathrm{O}(2)-\mathrm{U}(1)-\mathrm{N}(2)=79.9(2)^{\circ}\right)$ and the symmetric uranyl stretch of this complex is clearly observed in the Raman spectrum. This suggests the type of distortion enforced by the maleonitrile containing ligand influences the vibrational properties of the uranyl moiety than just the extent of distortion of the donor atoms away from the uranyl equational plane.

The oxygen of the coordinated water molecule in complex 1. $\left(\mathrm{CH}_{3} \mathrm{CH}_{2}\right) \mathrm{O}$ does not deviate outside the uranyl equatorial plane $\left(\mathrm{O}(1)-\mathrm{U}(1)-\mathrm{O}(5)=89.09(15)^{\circ}\right.$ and $\mathrm{O}(2)-\mathrm{U}(1)-\mathrm{O}(5)=$ $\left.90.03(15)^{\circ}\right)$ due to the monodentate nature of the water ligand

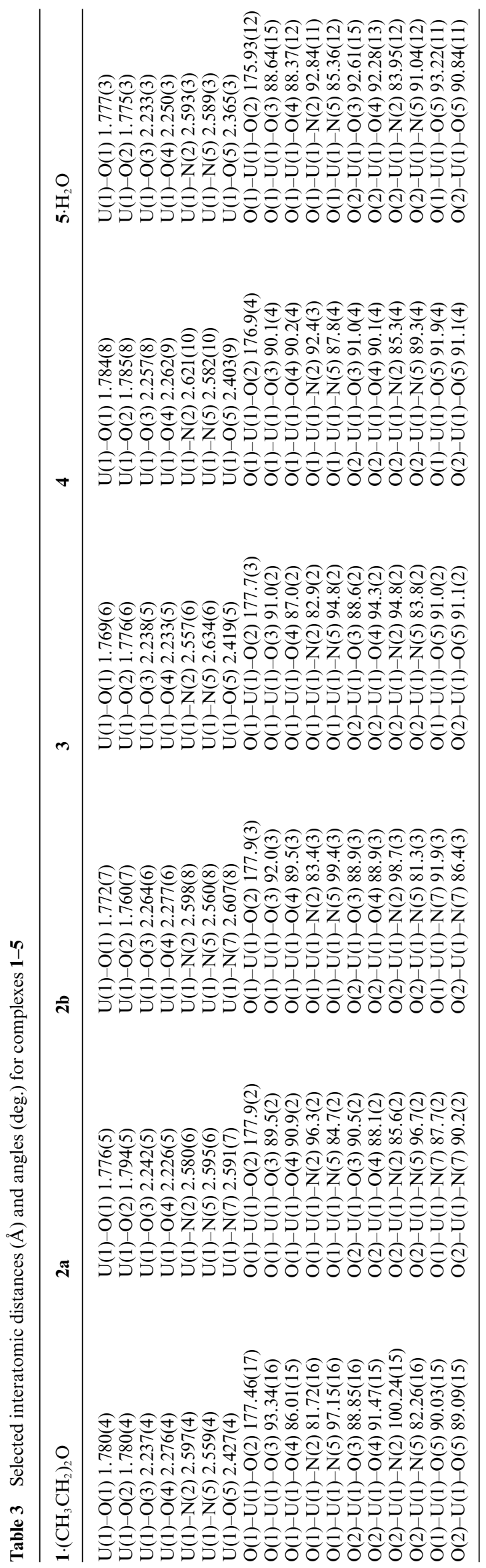


Table 4 Selected interatomic distances ( $)$ and angles (deg.) for $\left[\mathrm{UO}_{2}\right.$ (salophen)(py)] and $\left[\mathrm{UO}_{2}(\right.$ salen $\left.)(\mathrm{TPPO})\right] \cdot \mathrm{TPPO}$

\begin{tabular}{ll}
\hline$\left[\mathrm{UO}_{2}\right.$ (salophen)(py)] & {$\left[\mathrm{UO}_{2}\right.$ (salen)(TPPO)].TPPO } \\
\hline $\mathrm{U}(1)-\mathrm{O}(1) 1.790(3)$ & $\mathrm{U}(1)-\mathrm{O}(1) 1.790(5)$ \\
$\mathrm{U}(1)-\mathrm{O}(2) 1.791(3)$ & $\mathrm{U}(1)-\mathrm{O}(2) 1.786(5)$ \\
$\mathrm{U}(1)-\mathrm{O}(3) 2.249(3)$ & $\mathrm{U}(1)-\mathrm{O}(3) 2.259(5)$ \\
$\mathrm{U}(1)-\mathrm{O}(4) 2.242(3)$ & $\mathrm{U}(1)-\mathrm{O}(4) 2.263(5)$ \\
$\mathrm{U}(1)-\mathrm{N}(1) 2.554(4)$ & $\mathrm{U}(1)-\mathrm{N}(1) 2.589(6)$ \\
$\mathrm{U}(1)-\mathrm{N}(2) 2.547(4)$ & $\mathrm{U}(1)-\mathrm{N}(2) 2.586(6)$ \\
$\mathrm{U}(1)-\mathrm{N}(3) 2.583(4)$ & $\mathrm{U}(1)-\mathrm{O}(5) 2.396(5)$ \\
$\mathrm{O}(1)-\mathrm{U}(1)-\mathrm{O}(2) 179.14(15)$ & $\mathrm{O}(1)-\mathrm{U}(1)-\mathrm{O}(2) 178.7(2)$ \\
$\mathrm{O}(1)-\mathrm{U}(1)-\mathrm{O}(3) 89.01(14)$ & $\mathrm{O}(1)-\mathrm{U}(1)-\mathrm{O}(3) 91.4(2)$ \\
$\mathrm{O}(1)-\mathrm{U}(1)-\mathrm{O}(4) 91.18(14)$ & $\mathrm{O}(1)-\mathrm{U}(1)-\mathrm{O}(4) 87.4(2)$ \\
$\mathrm{O}(1)-\mathrm{U}(1)-\mathrm{N}(1) 93.65(14)$ & $\mathrm{O}(1)-\mathrm{U}(1)-\mathrm{N}(1) 80.3(2)$ \\
$\mathrm{O}(1)-\mathrm{U}(1)-\mathrm{N}(2) 91.73(14)$ & $\mathrm{O}(1)-\mathrm{U}(1)-\mathrm{N}(2) 99.2(2)$ \\
$\mathrm{O}(2)-\mathrm{U}(1)-\mathrm{O}(3) 90.33(13)$ & $\mathrm{O}(2)-\mathrm{U}(1)-\mathrm{O}(3) 88.5(2)$ \\
$\mathrm{O}(2)-\mathrm{U}(1)-\mathrm{O}(4) 89.65(13)$ & $\mathrm{O}(2)-\mathrm{U}(1)-\mathrm{O}(4) 93.2(2)$ \\
$\mathrm{O}(2)-\mathrm{U}(1)-\mathrm{N}(1)$ 85.62(14) & $\mathrm{O}(2)-\mathrm{U}(1)-\mathrm{N}(1) 98.4(2)$ \\
$\mathrm{O}(2)-\mathrm{U}(1)-\mathrm{N}(2) 88.33(14)$ & $\mathrm{O}(2)-\mathrm{U}(1)-\mathrm{N}(2) 79.9(2)$ \\
$\mathrm{O}(1)-\mathrm{U}(1)-\mathrm{N}(3) 89.99(14)$ & $\mathrm{O}(1)-\mathrm{U}(1)-\mathrm{O}(5) 92.2(2)$ \\
$\mathrm{O}(2)-\mathrm{U}(1)-\mathrm{N}(3) 90.42(14)$ & $\mathrm{O}(2)-\mathrm{U}(1)-\mathrm{O}(5) 89.1(2)$ \\
\hline
\end{tabular}
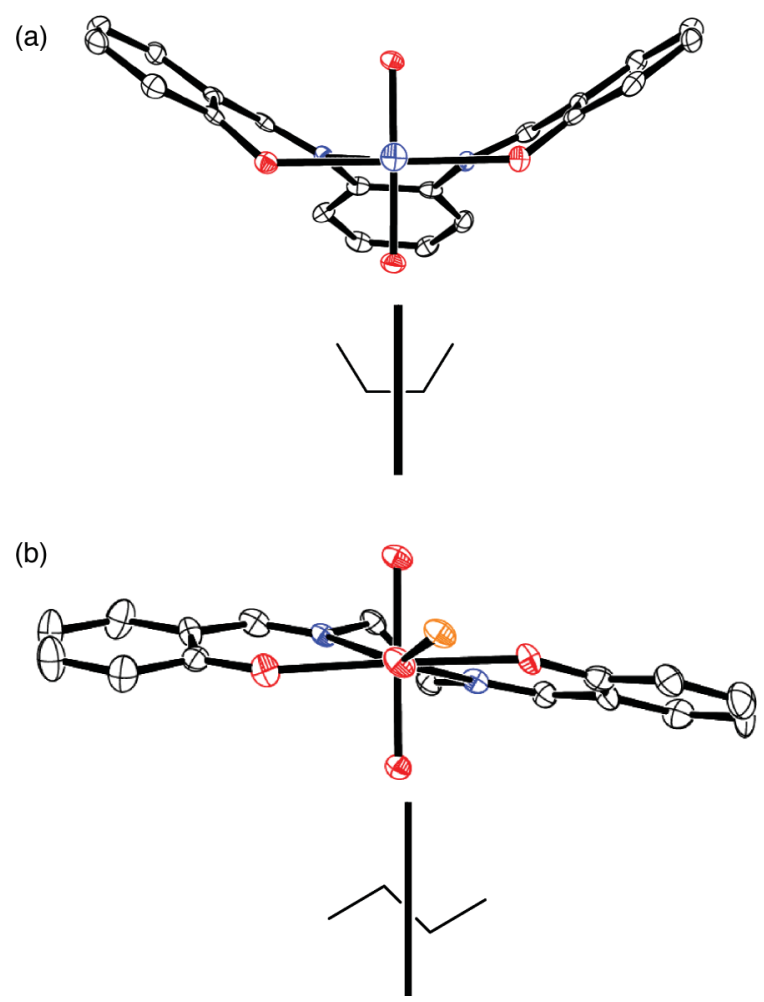

Fig. 7 ORTEP plots of the complex molecules of (a) $\left[\mathrm{UO}_{2}\right.$ (salophen)(py)] and (b) $\left[\mathrm{UO}_{2}\right.$ (salen)(TPPO)]-TPPO-view along molecular $\mathrm{C}_{2}$ axes with schematic diagrams indicating "boat" and "stepped" conformers, respectively (all hydrogens and all carbons on monodentate ligands omitted for clarity).

and its small steric bulk. The $\mathrm{U}-\mathrm{O}_{\left(\mathrm{H}_{2} \mathrm{O}\right)}$ distance in complex 1 (2.427(4) $\AA$ ) falls within the range of those distances observed for compounds containing the $\left[\mathrm{UO}_{2}\left(\mathrm{H}_{2} \mathrm{O}\right)_{5}\right]^{2+}$ cation $(2.36-2.46 \AA) .{ }^{30}$ However, $\mathrm{U}-\mathrm{O}_{\left.\mathrm{(H}_{2} \mathrm{O}\right)}$ distances in complexes with bulky tetradentate or bis(bidentate) ligands are typically longer than those observed for $\left[\mathrm{UO}_{2}\left(\mathrm{H}_{2} \mathrm{O}\right)_{5}\right]^{2+}$, up to $2.56 \AA{ }^{31}$ This suggests that the $\left(\text { salmnt } t^{\left(\mathrm{Et}_{2} \mathrm{~N}\right)_{2}}\right)^{2-}$ ligand enforces minimal steric strain on the coordination of water to complete the uranyl coordination sphere.
For complex 2, two crystal forms of the same molecular composition were isolated using the same synthetic procedure. Structure 2a (Fig. 8 and ESI $\dagger$ ) was solved in the monoclinic $P 2_{1} / n$ space group while structure $\mathbf{2 b}$ (ESI $\dagger$ ) was obtained in the triclinic $P-1$ space group. The asymmetric unit for 2a contains two crystallographically independent complex molecules while the asymmetric unit for $\mathbf{2} \mathbf{b}$ only has one complex molecule. In both these structures, the uranyl coordination sphere is completed by a pyridine ligand and the U- $\mathrm{N}_{\text {py }}$ distances (a: 2.591(7) and

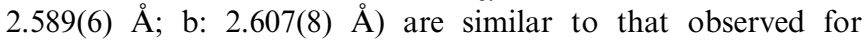
$\left[\mathrm{UO}_{2}\right.$ (salophen)(py)] (2.585(4) $\AA$, Table 5) and falls within the typical range of those distances for other uranyl complexes with coordinated pyridine(s) $\left(2.47-2.68 \AA{ }^{3}{ }^{32}\right.$ The $\mathrm{U}-\mathrm{N}_{\mathrm{py}}$ distances for previously reported uranyl complexes containing tetradentate Schiff base ligands tend to fall at the longer end of this range (2.61$2.65 \AA) .{ }^{33}$ The pyridine nitrogen does not deviate substantially outside of the uranyl equatorial plane (a: $\mathrm{O}(1)-\mathrm{U}(1)-\mathrm{N}(7)=$ $87.7(2)^{\circ}$ and $\mathrm{O}(2)-\mathrm{U}(1)-\mathrm{N}(7)=90.2(2)^{\circ} ; \mathrm{b}: \mathrm{O}(1)-\mathrm{U}(1)-\mathrm{N}(7)=$ $91.9(3)^{\circ}$ and $\left.\mathrm{O}(2)-\mathrm{U}(1)-\mathrm{N}(7)=86.4(3)^{\circ}\right)$. This shows that the $\left(\text { salmnt }^{\left(\mathrm{Et}_{2} \mathrm{~N}\right)_{2}}\right)^{2-}$ ligand, in a similar manner to that in complex 1, enforces little strain on the coordinated pyridine. Similar structural characteristics are observed for the coordination of the monodentate ligand for complexes 3-5. When pyridine is coordinated to uranyl, the orientation of the plane of the pyridine ligand relative to the linear uranyl moiety can alter substantially between complexes. The average dihedral angles between the plane of the pyridyl ligand and the linear uranium dioxo unit for complex $\mathbf{2 a}$ are $45(1)$ and $51(2)^{\circ}$, and for $\mathbf{2 b}$ is $65(3)^{\circ}$ while the same angle for $\left[\mathrm{UO}_{2}\right.$ (salophen)(py)] is $48(5)^{\circ}$. Previously reported structures of uranyl complexes with tetradentate Schiff bases with a coordination sphere completed by pyridine include $\left[\mathrm{UO}_{2}(\right.$ salen $\left.)(\mathrm{py})\right]$ and $\left[\mathrm{UO}_{2}(t\right.$-butylsalen $\left.)(\mathrm{py})\right]$ and these exhibit average dihedral angles between the plane of the pyridine ligand and the linear dioxo unit of $60(4)^{\circ}$ and $87(3)^{\circ}$, respectively. ${ }^{33}$ There seems to be little trend between the orientation of the coordinated pyridine ligand with the type of tetradentate ligand that completes the uranyl coordination sphere.

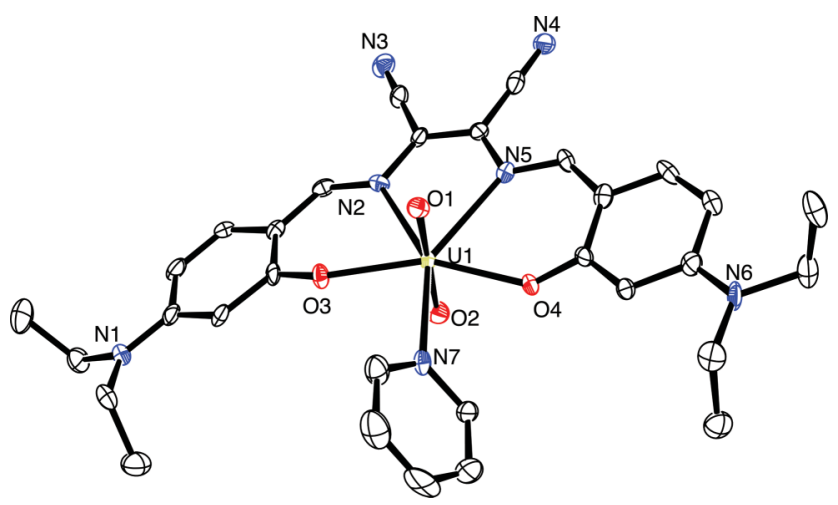

Fig. 8 ORTEP plot of the complex molecule of 2, with crystallographic numbering (hydrogens omitted).

Complexes 3 and $\mathbf{4}$ have DMSO and DMF molecules coordinated to the uranium centre, respectively. The U-O distances associated with these monodentate ligands (2.419(5) for 3 and 2.403(9) $\AA$ for 4) are similar to those of uranyl complexes with other tetradentate Schiff base ligands, like salophen ${ }^{2-}$ and salen ${ }^{2-}$, 


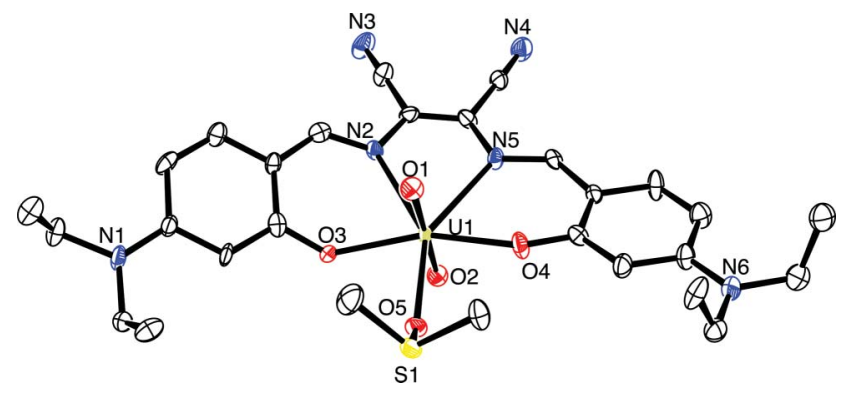

Fig. 9 ORTEP plot of the complex molecule of 3, with crystallographic numbering (hydrogens omitted).

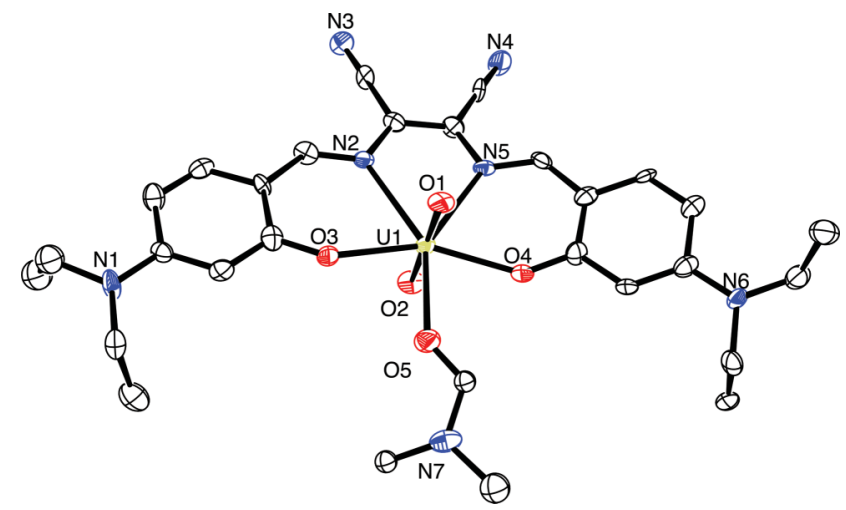

Fig. 10 ORTEP plot of the complex molecule of $\mathbf{4}$, with crystallographic numbering (hydrogens omitted).

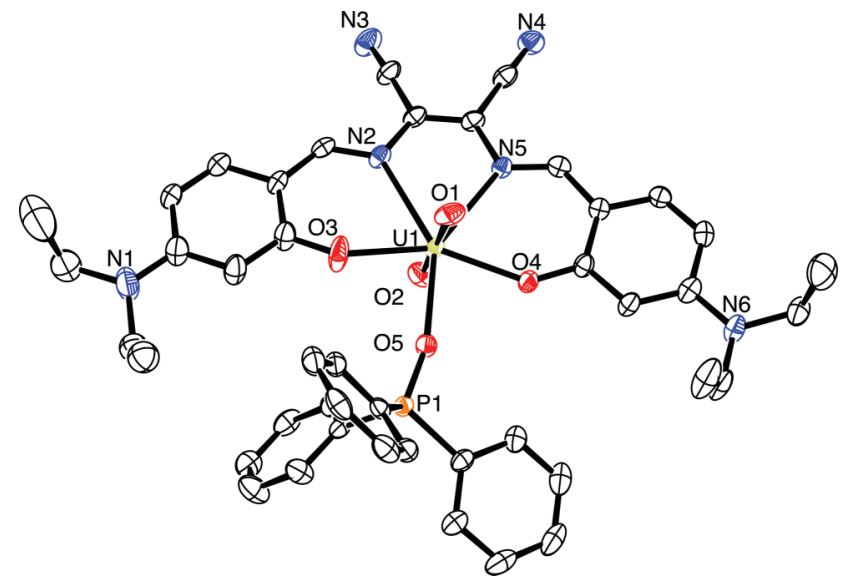

Fig. 11 ORTEP plot of the complex molecule of $\mathbf{5}$, with crystallographic numbering (hydrogens omitted).

where the coordination sphere is also completed by DMSO or $\mathrm{DMF}^{21}$ In complex $\mathbf{3}$, the methyl groups of the DMSO are both directed above the uranyl equatorial plane while in complex 4 the coordinated DMF is disordered between two sites, but in both disordered forms the entire DMF ligand is effectively coplanar with the uranyl equatorial plane.

A TPPO molecule completes the uranyl coordination environment in complex 5 with a water of crystallization found in the asymmetric unit. The $\mathrm{U}-\mathrm{O}_{\text {TPPO }}$ distance in 5 is $2.365(3) \AA$ which is similar to that observed for $\left[\mathrm{UO}_{2}\right.$ (salen)(TPPO)] (2.396(5) $\AA$; $\mathrm{ESI} \dagger$ and Table 5), falling within the range of $\mathrm{U}-\mathrm{O}$ distances for uranyl complexes with TPPO $(2.29-2.40 \AA) .{ }^{34}$
Table 5 Formal redox half potentials $\left(v s . \mathrm{Fc}^{+} / \mathrm{Fc}\right)$ for the $\mathrm{U}(\mathrm{vI}) / \mathrm{U}(\mathrm{v})$ couple of $\left[\mathrm{UO}_{2}\left(\eta^{4}-\mathrm{L}^{\prime}\right)\left(\eta^{1}-\mathrm{L}^{\prime \prime}\right)\right]$ complexes

\begin{tabular}{lllll}
\hline & \multicolumn{4}{l}{$\mathrm{L}^{\prime \prime}$} \\
\cline { 2 - 5 } $\mathrm{L}^{\prime}$ & $\mathrm{Py}$ & $\mathrm{DMSO}$ & $\mathrm{DMF}$ & $\mathrm{TPPO}$ \\
\hline salen $^{2-}$ & $-1.61^{a}$ & $-1.57^{c}$ & $-1.67^{e, f}$ & Irreversible \\
salophen $^{2-}$ & $-1.57^{a}$ & $-1.550^{c, d}$ & $-1.626^{d, e}$ & Irreversible \\
(salmnt $\left.^{\left(\mathrm{Et}_{2} \mathrm{~N}_{2}\right.}\right)^{2-}$ & $-1.80^{b}$ & $-1.78^{b}$ & $-1.81^{b}$ & $-1.78^{b}$ \\
& $-1.79^{a}$ & $-1.66^{c}$ & $-1.60^{e}$ & \\
& $\mathbf{( 2 )}$ & $\mathbf{( 3 )}$ & $\mathbf{( 4 )}$ & $\mathbf{( 5 )}$
\end{tabular}

${ }^{a}$ In py ${ }^{b} \operatorname{In} \mathrm{DCM}^{c}$ In DMSO ${ }^{d}$ Ref. $5^{e} \operatorname{In} \mathrm{DMF}^{f}$ Ref. 6

\section{Electrochemistry}

The uranium and ligand centred redox processes of complexes 25 were probed using cyclic voltammetry and compared to those of analogous complexes, $\left[\mathrm{UO}_{2}(\right.$ salen $\left.)(\mathrm{L})\right]$ and $\left[\mathrm{UO}_{2}\right.$ (salophen)(L)], where $\mathrm{L}=$ py, DMSO, DMF and TPPO. All reported potentials are referenced to the ferrocenium/ferrocene $\left(\mathrm{Fc}^{+} / \mathrm{Fc}\right)$ redox couple.

The cyclic voltammograms of the protonated neutral ligand, salmnt ${ }^{\left(\mathrm{Et}_{2} \mathrm{~N}_{2}\right.} \mathrm{H}_{2}$, in $0.1 \mathrm{M} \mathrm{Bu}_{4} \mathrm{NPF}_{6}$ in dichloromethane all show at least two irreversible reductive processes (ESI $\dagger$ ). These cathodic peaks are broad, centered at $\sim-1.8$ and $\sim 2.4 \mathrm{~V}\left(v s . \mathrm{Fc}^{+} / \mathrm{Fc}\right)$, and were sometimes observed as shoulders near the end of the electrochemical window of this system. These cathodic processes are due to the reduction of the cyano groups, the central alkene bond and/or the imine units. The anodic sweeps clearly show at least two irreversible oxidative processes at +0.57 and $+0.81 \mathrm{~V}$ ( $v s$. $\mathrm{Fc}^{+} / \mathrm{Fc}$ ). The process indicated by the anodic peak at $+0.57 \mathrm{~V}$ (vs. $\mathrm{Fc}^{+} / \mathrm{Fc} ; 100 \mathrm{mV} \mathrm{s}^{-1}$ ) does not show any reversible character irrespective of the position of the switching potential relative to the second oxidative process at $+0.81 \mathrm{~V}\left(v s\right.$. $\left.\mathrm{Fc}^{+} / \mathrm{Fc}\right)$. These irreversible oxidative processes are likely to involve the formation of radical species and/or quinone systems similar to those found in the oxidation of catecholate. ${ }^{35}$ Similar observations were obtained for the redox behaviour of salmnt ${ }^{\left(\mathrm{Et}_{2} \mathrm{~N}_{2}\right.} \mathrm{H}_{2}$ in different solvents (i.e. py, DMSO, DMF).

The cyclic voltammograms of uranyl complexes 2-5 (Fig. 12 and ESI $\dagger$ ) in DCM all exhibit a reversible redox process at $\sim-1.80 \mathrm{~V}$ (vs. $\mathrm{Fc}^{+} / \mathrm{Fc}$ ) which is most likely due to the $\left\{\mathrm{UO}_{2}\right\}^{2+} /\left\{\mathrm{UO}_{2}\right\}^{+}$ couple (Table 5). Most uranyl complexes with tetradentate Schiff

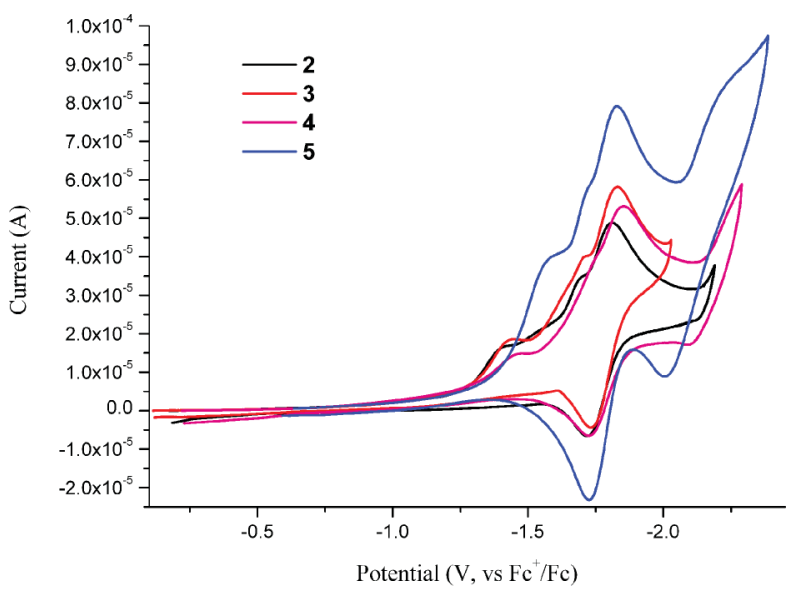

Fig. 12 Cyclic voltammograms of $\mathbf{2}-\mathbf{5}$ from $\sim-0.2$ to $\sim-2.5 \mathrm{~V}$ (vs. $\mathrm{Fc}^{+} / \mathrm{Fc}$; $0.1 \mathrm{M} \mathrm{Bu}_{4} \mathrm{NPF}_{6}$ in DCM; $200 \mathrm{mV} \mathrm{s}^{-1}$; initial scan direction = cathodic). 
base ligands (e.g. salen ${ }^{2-}$ and salophen ${ }^{2-}$ ) display a reversible $\left\{\mathrm{UO}_{2}\right\}^{2+} /\left\{\mathrm{UO}_{2}\right\}^{+}$couple between -1.5 and $-1.7 \mathrm{~V}\left(v s . \mathrm{Fc}^{+} / \mathrm{Fc}\right.$; Table 5). The complexes with (salmnt $\left.{ }^{\left(\mathrm{Et}_{2} \mathrm{~N}_{2}\right.}\right)^{2-}$ have some of the most negative half potentials for the $\left\{\mathrm{UO}_{2}\right\}^{2+} /\left\{\mathrm{UO}_{2}\right\}^{+}$couple observed to date, probably caused by strong electron donation from the (salmnt $\left.t^{\left(\mathrm{Et}_{2} \mathrm{~N}\right)_{2}}\right)^{2-}$ ligand to the uranium centre. Changing the monodentate ligand has little influence on the uranyl redox properties of these complexes. The only other reported complexes with a negative $\left\{\mathrm{UO}_{2}\right\}^{2+} /\left\{\mathrm{UO}_{2}\right\}^{+}$redox potential of similar magnitude are mixed ligand species with the tetradentate ligand $\left(\operatorname{salan}-{ }^{t} \mathrm{Bu}_{2}\right)^{2-}$ and the uranyl coordination sphere completed by a pyridine molecule (salan- ${ }^{t} \mathrm{Bu}_{2}=N, N^{\prime}$-bis(2-hydroxybenzyl-3,5di-tert-butyl)- $N, N^{\prime}$-dimethyl-1,2-ethylenediaminate). ${ }^{36}$ The cyclic voltammograms of [Zn(salmnt $\left.\left.{ }^{\left(\mathrm{E}_{2} \mathrm{~N}_{2}\right.}\right)\right]$ in DCM (ESI $\dagger$ ) display an irreversible redox process assigned to a ligand-based reduction, which occurs at slightly more negative potentials $\left(E_{\mathrm{pc}} \sim-1.95\right.$ vs. $\mathrm{Fc}^{+} / \mathrm{Fc}$ ) than those assigned to the $\left\{\mathrm{UO}_{2}\right\}^{2+} /\left\{\mathrm{UO}_{2}\right\}^{+}$couple for complexes 2-5. The similar potentials at which both the uranyl and ligand-based reduction processes are expected to occur for 2-5 may indicate the possibility of these complexes, upon reduction, exhibiting non-innocent behaviour. The exact nature of these reduction processes will be explored further using spectroelectrochemical techniques.

It is clear that the $\mathrm{U}(\mathrm{VI})$ oxidation state is highly stabilised in these complexes (2-5), irrespective of any possible ligand reduction. For the uranyl complexes with $\left(\operatorname{salan}-{ }^{t} \mathrm{Bu}_{2}\right)^{2-}$ the $\mathrm{U}(\mathrm{vI})$ stabilisation is explained by density functional theory calculations which show the strong $\pi$-donor character of the $\left(\operatorname{salan}-{ }^{t} \mathrm{Bu}_{2}\right)^{2-}$ ligand..$^{36}$ Clark et al. have postulated that ligand $\pi$-donor orbitals can mix with uranium $6 \mathrm{~d}$ orbitals stabilising higher uranium oxidation states. ${ }^{37}$ Therefore, it is most likely the position of the $\left\{\mathrm{UO}_{2}\right\}^{2+} /\left\{\mathrm{UO}_{2}\right\}^{+}$redox potentials for complexes $\mathbf{2 - 5}$ is due to strong $\pi$-donation from the highly conjugated (salmnt $\left.{ }^{\left(\mathrm{Et}_{2} \mathrm{~N}_{2}\right.}\right)^{2-}$ ligand, influenced by the electron donating $\mathrm{Et}_{2} \mathrm{~N}$ substituents, to the uranium $6 \mathrm{~d}$ orbitals.

The cyclic voltammetry profiles for $\mathbf{2}-\mathbf{5}$ at reducing potentials in DCM (Fig. 12) display a number of shoulders of relatively weak intensity on the cathodic peak. Similar shoulders are observed in the same profiles for $\left[\mathrm{Zn}\left(\mathrm{salmnt}^{\left(\mathrm{Et}_{2} \mathrm{~N}_{2}\right)}\right)\right.$ (ESI $\dagger$ ) indicating that ligand reduction processes may precede the uranyl reduction for complexes 2-5. There is also the possibility that these observations may be due to ligand exchange processes occurring, either from dissociation of the monodentate ligand and/or partial dissociation of the tetradentate ligand to a lower denticity form. NMR spectroscopy of $\mathbf{2}$ and $\mathbf{4}$ at room temperature show the monodentate ligand in these complexes undergoes exchange at the NMR timescale (see Synthesis and NMR spectroscopy section). If dissociation of the monodentate ligand was the only cause of these multiple reduction processes it would be expected that just a single uranyl centred reduction would be observed by cyclic voltammetry when a vast excess of the monodentate ligand is present in solution. Cyclic voltammetry for 2-4 using the monodentate ligand as solvent for each of the respective complexes (Fig. 13) clearly shows a cathodic peak $\left(\sim 1.4 \mathrm{~V}\right.$, vs. $\left.\mathrm{Fc}^{+} / \mathrm{Fc}\right)$ preceding the reversible uranyl redox couple. The intensity of this peak at $\sim 1.4 \mathrm{~V}\left(v s . \mathrm{Fc}^{+} / \mathrm{Fc}\right)$ generally increases, relative to the intensities of the peaks of the reversible process, with increasing solution purge $\left(\mathrm{N}_{2}\right)$ times preceding the measurements. The most likely explanation for these observations is the partial dissociation of

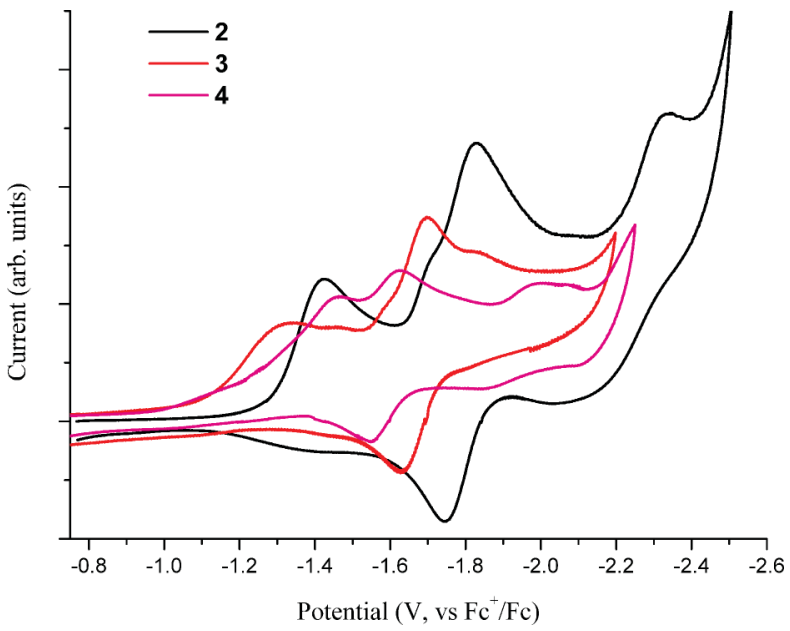

Fig. 13 Cyclic voltammograms of $\left[\mathrm{UO}_{2}\left(\operatorname{salmnt}^{\left(\mathrm{Et}_{2} \mathrm{~N}\right)_{2}}\right)(\mathrm{L})\right]$ in $\mathrm{L}(\mathrm{L}=$ py, DMSO, DMF) from $\sim-0.8$ to $\sim-2.4 \mathrm{~V}$ (vs. $\mathrm{Fc}^{+} / \mathrm{Fc} ; 0.1 \mathrm{M} \mathrm{Bu}_{4} \mathrm{NPF}_{6}$; $200 \mathrm{mV} \mathrm{s}^{-1}$; initial scan direction $=$ cathodic $)$.

the (salmnt $\left.{ }^{\left(\mathrm{E}_{2} \mathrm{~N} / 2\right.}\right)^{2-}$ ligand in the presence of competing ligands to a complex where the original tetradentate ligand is coordinating with a lower denticity. This occurs for the $\mathrm{U}(\mathrm{VI})$ oxidation state only, with a single peak assigned to the intact complex observed for the anodic scan. A similar explanation has been used to justify the redox behaviour of $\left[\mathrm{UO}_{2}(\mathrm{salen})(\mathrm{DMF})\right]$ in DMF but with partial dissociation of the salen ${ }^{2-}$ occurring only after reduction to the $\mathrm{U}(\mathrm{v})$ form. ${ }^{6}$ Further evidence for the dissociation of the (salmnt $\left.{ }^{\left(\mathrm{Et}_{2} \mathrm{~N}_{2}\right.}\right)^{2-}$ ligand is provided by the solution behaviour of complex 1 where NMR spectroscopy shows ligand dissociation occurring upon dissolution in DCM and the difficulties observed in synthesising 1 under different reaction conditions. Another cathodic peak is observed at $\sim-2.0 \mathrm{~V}$ in some scans which is assigned to a ligand-based reduction when $\left(\operatorname{salmnt}^{\left(\mathrm{Et}_{2} \mathrm{~N}_{2}\right)^{2-}}\right.$ is bound in the lower denticity form.

A reversible process assigned to the $\left\{\mathrm{UO}_{2}\right\}^{2+} /\left\{\mathrm{UO}_{2}\right\}^{+}$redox couple is still observed for complexes $\mathbf{2 - 4}$ in the appropriate coordinating solvent even though exchange processes are evident (Fig. 13). For complex 2 , the half potential $\left(-1.79 \mathrm{~V}\right.$, vs. $\left.\mathrm{Fc}^{+} / \mathrm{Fc}\right)$ does not shift relative to the value obtained in DCM (Table 5). However, for complexes 3 and $\mathbf{4}$ in DMSO and DMF, respectively, the half potentials $\left(3:-1.66 \mathrm{~V} ; 4:-1.60 \mathrm{~V}\right.$, vs. $\left.\mathrm{Fc}^{+} / \mathrm{Fc}\right)$ shift to less negative values by $\sim 0.2 \mathrm{~V}$ relative to those obtained in DCM (Table 5). This indicates the solvation environment plays a subtle role in the redox properties of uranyl complexes. Density functional theory calculations of various uranyl complexes in aqueous solution have shown the role solvation plays in determining actinyl redox properties. ${ }^{38}$ Specifically, how the presence of solvent hydrogen bonding with the uranyl oxygens, or lack thereof, influences actinyl behaviour. ${ }^{38}$ This shows that similar considerations need to be applied in order to fully understand actinyl redox behaviour in protic vs. aprotic organic solvents.

It has been previously postulated that the $\left\{\mathrm{UO}_{2}\right\}^{2+} /\left\{\mathrm{UO}_{2}\right\}^{+}$ redox potential for uranyl complexes shifts to more negative values simply with increasing denticity of the coordinating ligands. ${ }^{6}$ Although there is a body of evidence that supports this argument (Tables 5 and 6) it is becoming increasingly clear, with more experimental evidence, that the main influence on the potential for the $\mathrm{U}(\mathrm{VI}) / \mathrm{U}(\mathrm{v})$ couple of uranyl complexes is the level of 
Table 6 Formal redox half potentials $\left(v s . \mathrm{Fc}^{+} / \mathrm{Fc}\right)$ for the $\mathrm{U}(\mathrm{vI}) / \mathrm{U}(\mathrm{v})$ couple of selected uranyl complexes

\begin{tabular}{|c|c|c|c|c|c|}
\hline$\left\{\mathrm{UO}_{2}\right\}^{2+}$ complex & Charge of $\left\{\mathrm{UO}_{2}\right\}^{2+}$ complex & Maximum ligand denticity & Solvent & $E^{\circ} / \mathrm{V}$ & Ref. \\
\hline$\left[\mathrm{UO}_{2}\left(\mathrm{CO}_{3}\right)_{3}\right]^{4-}$ & -4 & Bidentate & $\mathrm{H}_{2} \mathrm{O}$ & -1.00 & 39 \\
\hline$\left[\mathrm{UO}_{2}(\mathrm{OH})_{5}\right]^{3-}$ & -3 & Monodentate & $\mathrm{H}_{2} \mathrm{O}$ & -1.11 & 39 \\
\hline$\left[\mathrm{UO}_{2} \mathrm{Cl}_{4}\right]^{2-}$ & -2 & Monodentate & $\mathrm{H}_{2} \mathrm{O}$ & -0.24 & 39 \\
\hline$\left[\mathrm{UO}_{2}\left(\mathrm{MeCO}_{2}\right)_{3}\right]^{-}$ & -1 & Bidentate & $\mathrm{H}_{2} \mathrm{O}$ & -0.57 & 39 \\
\hline$\left[\mathrm{UO}_{2}(\mathrm{acac})_{2}(\mathrm{DMSO})\right]^{a}$ & 0 & Bidentate & DMSO & -1.44 & 7 \\
\hline$\left[\mathrm{UO}_{2}(\mathrm{acac})_{2}(\mathrm{DMF})\right]^{a}$ & 0 & Bidentate & DMF & -1.47 & 6 \\
\hline$\left[\mathrm{UO}_{2}\left({ }^{A r} \mathrm{acnac}\right)_{2}\right]^{c}$ & 0 & Bidentate & DCM & -1.52 & 10 \\
\hline$\left[\mathrm{UO}_{2}\left(\text { salophen }-{ }^{t} \mathrm{Bu}_{2}\right)(\mathrm{py})\right]^{d}$ & 0 & Tetradentate & py & -1.67 & 36 \\
\hline$\left[\mathrm{UO}_{2}\left(\operatorname{salan}-{ }^{t} \mathrm{Bu}_{2}\right)(\mathrm{py})\right]^{e}$ & 0 & Tetradentate & py & -1.82 & 36 \\
\hline$\left[\mathrm{UO}_{2}\left(\mathrm{H}_{2} \mathrm{O}\right)_{5}\right]^{2+}$ & +2 & Monodentate & $\mathrm{H}_{2} \mathrm{O}$ & -0.35 & 39 \\
\hline$\left[\mathrm{UO}_{2}(\mathrm{DMSO})_{5}\right]^{2+}$ & +2 & Monodentate & DMSO & -0.98 & 6 \\
\hline$\left[\mathrm{UO}_{2}(\mathrm{DMF})_{5}\right]^{2+}$ & +2 & Monodentate & DMF & -0.89 & 6 \\
\hline
\end{tabular}

${ }^{a}$ acac $=$ acetylacetonate ${ }^{b} \mathrm{dbm}=$ dibenzoylmethanate ${ }^{c}{ }^{A r}$ acnac $=\left(\left(2,4,6-\mathrm{Me}_{3} \mathrm{C}_{6} \mathrm{H}_{2}\right) \mathrm{NC}(\mathrm{Ph}) \mathrm{CHC}(\mathrm{Ph}) \mathrm{O}\right)^{-}{ }^{d}$ salophen- ${ }^{t} \mathrm{Bu}{ }_{2}=N, N^{\prime}$-bis $(3,5-d i-t e r t-$ butylsalicylidene)-1,2-phenylenediaminate ${ }^{e}$ salan- ${ }^{t} \mathrm{Bu}_{2}=N, N^{\prime}$-bis(2-hydroxybenzyl-3,5-di-tert-butyl)- $N, N^{\prime}$-dimethyl-1,2-ethylenediaminate

$\pi$-donation from the ligand environment while subtle modulation of this couple may be achieved by altering the solvation sphere.

The cyclic voltammograms of uranyl complexes 2-5 in DCM at positive potentials ( $v s$. $\mathrm{Fc}^{+} / \mathrm{Fc}$ ) exhibit a number of features that can be attributed to $\left(\mathrm{salmnt}^{\left(\mathrm{Et}_{2} \mathrm{~N}\right)_{2}}\right)^{2-}$ ligand-based redox processes (Fig. 14 and ESI $\dagger$ ). Complex 2 has two anodic features at +0.50 and $+0.71 \mathrm{~V}$ (vs. $\mathrm{Fc}^{+} / \mathrm{Fc}$ ) while three features can be resolved in the voltammograms for complexes $3(+0.45,+0.69$ and $+0.84 \mathrm{~V}$ : vs. $\left.\mathrm{Fc}^{+} / \mathrm{Fc}\right)$ and $4\left(+0.45,+0.68\right.$ and $+0.86 \mathrm{~V}$ : vs. $\left.\mathrm{Fc}^{+} / \mathrm{Fc}\right)$. The cyclic voltammograms of complex $\mathbf{5}$ exhibit three anodic peaks at scan rates slower than $150 \mathrm{mV} \mathrm{s}^{-1}(+0.40,+0.71$ and $+0.89 \mathrm{~V}$, vs. $\mathrm{Fc}^{+} / \mathrm{Fc} ; 25 \mathrm{mV} \mathrm{s}^{-1}$ ), but the two anodic peaks at more positive potentials merge into one at faster scan rates $(+0.43$ and $+0.80 \mathrm{~V}$, vs. $\mathrm{Fc}^{+} / \mathrm{Fc} ; 600 \mathrm{mV} \mathrm{s}^{-1}$ ). All of these redox processes are seen to be electrochemically irreversible when the switching potential is set to $+1.28 \mathrm{~V}\left(v s . \mathrm{Fc}^{+} / \mathrm{Fc}\right)$ or more positive potentials. When the switching potential is set to $\sim+0.6 \mathrm{~V}\left(v s . \mathrm{Fc}^{+} / \mathrm{Fc}\right)$, between the least positive and most positive anodic features, the redox process at the least positive potential begins to exhibit more reversible characteristics for complexes 2-5 (Fig. 15 and ESI $\dagger$ ). For complex 2 , the $i_{\mathrm{pa}} / i_{\mathrm{pc}}$ ratios of this redox process are very large for all scan rates demonstrating a predominantly irreversible process. However, those ratios for complex $\mathbf{5}$ are less than 1.5 indicating a more reversible redox process centred at $+0.40 \mathrm{~V}$ ( $v s$.

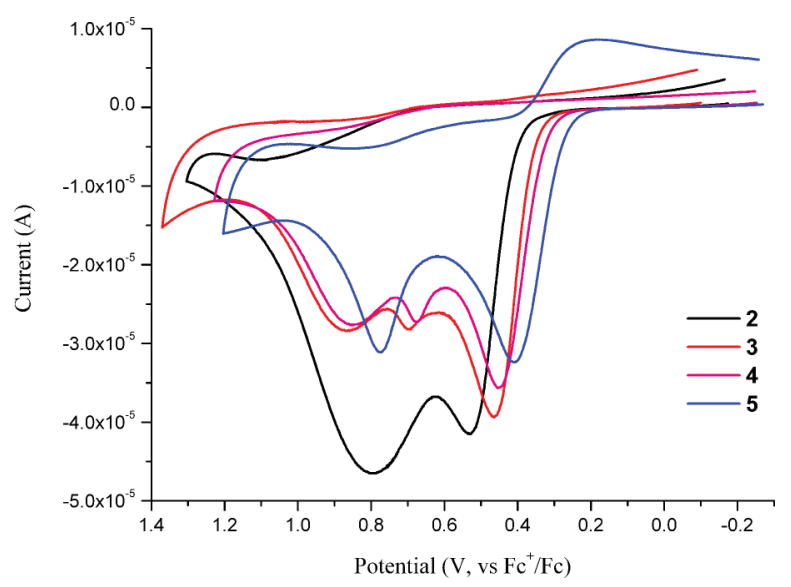

Fig. 14 Cyclic voltammograms of 2-5 from $\sim-0.2$ to $\sim 1.3 \mathrm{~V}\left(v s . \mathrm{Fc}^{+} / \mathrm{Fc}\right.$; $0.1 \mathrm{M} \mathrm{Bu}_{4} \mathrm{NPF}_{6}$ in DCM; $200 \mathrm{mV} \mathrm{s}^{-1}$; initial scan direction $=$ anodic $)$.

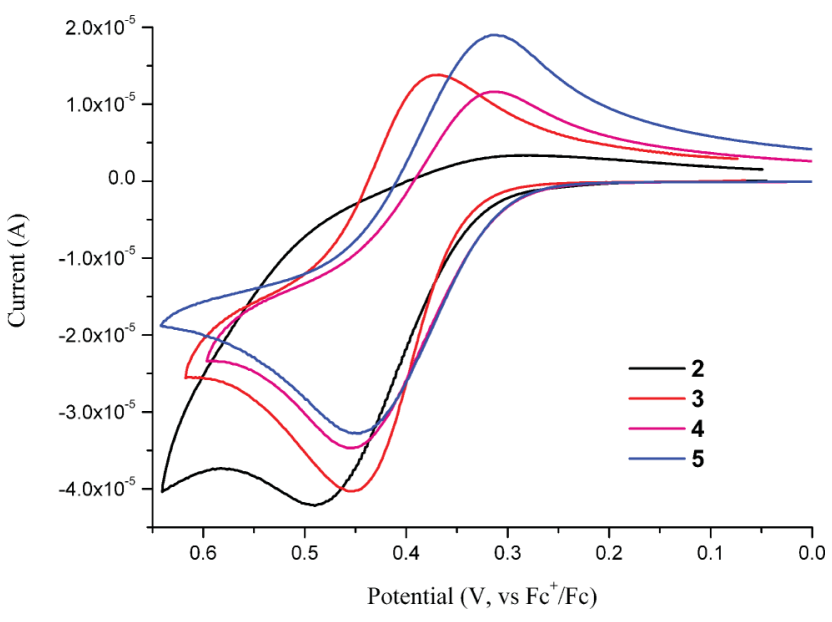

Fig. 15 Cyclic voltammograms of $2-5$ from $\sim 0.0$ to $\sim 0.6 \mathrm{~V}\left(v s . \mathrm{Fc}^{+} / \mathrm{Fc}\right.$; $0.1 \mathrm{M} \mathrm{Bu}_{4} \mathrm{NPF}_{6}$ in DCM; $200 \mathrm{mV} \mathrm{s}^{-1}$; initial scan direction = anodic).

$\left.\mathrm{Fc}^{+} / \mathrm{Fc}\right)$. Complexes 3 and $\mathbf{4}$ exhibit redox processes centred at +0.40 and $+0.41 \mathrm{~V}\left(v s . \mathrm{Fc}^{+} / \mathrm{Fc}\right)$, respectively, that show reversible characteristics with peak current ratios $\left(i_{\mathrm{pa}} / i_{\mathrm{pc}}\right)$ between those observed for complexes $\mathbf{2}$ and 5. The potentials for these ligandbased redox features are generally shifted to less positive potentials compared to those observed for salmnt ${ }^{\left(\mathrm{Et}_{2} \mathrm{~N}_{2}\right.} \mathrm{H}_{2}$. It is most likely that these redox processes at positive potentials are due to the formation of radical and/or quinone species of the $\left(\mathrm{salmnt}^{\left(\mathrm{Et}_{2} \mathrm{~N}\right)_{2}}\right)^{2-}$ ligand and demonstrate the possibility that these maleonitrilecontaining complexes can be used as precursors for the isolation of actinyl complexes with radical containing ligands.

For each of the complexes $\mathbf{2 - 4}$ in the same solvent as the monodentate ligand (ESI $\dagger$ ), only two ligand-based anodic processes are resolved, sometimes as shoulders on the edge of the electrochemical window, and neither of these exhibit any reversible behaviour. Thus, the solvent dependency on the electrochemical behaviour of uranyl complexes of (salmnt $\left.{ }^{\left(\mathrm{Et}_{2} \mathrm{~N}_{2}\right.}\right)^{2-}$ applies to both ligand and metal centred redox processes. Redox processes at positive potentials are also observed for [ $\mathrm{UO}_{2}$ (salophen)(L)] and $\left[\mathrm{UO}_{2}(\right.$ salen $\left.)(\mathrm{L})\right]$ in $\mathrm{L}(\mathrm{L}=$ py, DMSO, DMF; ESI $\dagger)$, and $\left[\mathrm{UO}_{2}\right.$ (salophen)(TPPO)] and $\left[\mathrm{UO}_{2}\right.$ (salen)(TPPO) $]$ in DCM but only one or two features are typically resolved in the potential range of +0.8 to $+1.3 \mathrm{~V}$ and no reversible characteristics for these 
processes are seen. The reversible characteristics of the feature at the least positive potential for complexes 2-5 are not repeated for the protonated free ligand, and indicate the complexing metal in conjunction with the solvation environment plays an influential role in the redox behaviour of the (salmnt $\left.{ }^{\left(\mathrm{Et}_{2} \mathrm{~N}_{2}\right.}\right)^{2-}$ ligand.

\section{Experimental}

Caution. Both natural and depleted uranium were used during the course of these experiments. As well as the radioactive hazards associated with ${ }^{238} \mathrm{U}$ and ${ }^{235} \mathrm{U}$, uranium is a toxic metal, and care should be taken with all manipulations.

\section{Physical measurements}

${ }^{1} \mathrm{H},{ }^{13} \mathrm{C}\left\{{ }^{1} \mathrm{H}\right\},{ }^{13} \mathrm{C}$ DEPT, COSY and ${ }^{31} \mathrm{P}$ NMR spectra were recorded with a Bruker Avance Ultrashield $400 \mathrm{MHz}$ spectrometer at $298 \mathrm{~K}$ using the appropriate deuterated solvent as a lock with $5 \mathrm{~mm}$ diameter NMR tubes. ${ }^{13} \mathrm{C}$ and ${ }^{1} \mathrm{H}$ NMR spectra obtained for samples in $\mathrm{d}_{2}$-DCM were internally referenced to tetramethylsilane at $\delta 0.0 \mathrm{ppm}$. All other ${ }^{1} \mathrm{H}$ and ${ }^{13} \mathrm{C}$ spectra were referenced to residual protio solvent peaks $\left({ }^{1} \mathrm{H}\right)$ as internal standards or the characteristic resonances of solvent nuclei $\left({ }^{13} \mathrm{C}\right)$. ${ }^{31} \mathrm{P}$ chemical shifts were externally referenced to $\mathrm{H}_{3} \mathrm{PO}_{4}(85 \%)$. Elemental analysis was carried out using a Carlo Erba Instruments CHNS-O EA1 108 elemental analyzer (C, H, N, S and P analyses) and a Fisons Horizon Elemental Analysis ICPOES spectrometer (U analysis). Solution state electronic absorption spectroscopy measurements were recorded using a Cary Varian 500 Scan UVvis-NIR spectrophotometer, typically over the scan range 200$800 \mathrm{~nm}$ at a scan rate of $600 \mathrm{~nm} \mathrm{~min}{ }^{-1}$. All photophysical data were obtained on a JobinYvon-Horiba Fluorolog spectrometer fitted with a JY TBX picosecond photodetection module and a Hamamatsu R5509-73 detector (cooled to $-80{ }^{\circ} \mathrm{C}$ using a C9940 housing). Lifetimes were obtained using the JY-Horiba FluoroHub single photon counting module in conjunction with NanoLEDs for 355 or $372 \mathrm{~nm}$ pulsed (1 MHz) output. Vibrational spectra (Infrared and Raman) of solid samples were recorded using a Bruker Equinox 55/Bruker FRA 106/5 spectrometer with a coherent $500 \mathrm{~mW}$ laser. IR measurements were obtained as attenuated total reflectance (ATR) spectra using a "Golden Gate" attachment. Raman spectra were acquired with the Bruker FRA 106/5 spectrometer using a diode-pumped, air-cooled Nd: YAG laser source $(1064 \mathrm{~nm})$. A DeltaNu Advantage 785 near-infrared bench top Raman spectrometer, using a laser excitation wavelength of $785 \mathrm{~nm}$, was also used to obtain Raman spectra of solid samples. Electrospray (+/-) ionisation mass spectrometry was performed using a Micromass Platform spectrometer.

\section{Syntheses}

General. Diaminomaleonitrile, 4-diethylaminosalicylaldehyde and triphenylphosphine oxide (TPPO) were obtained from Aldrich and used as supplied. Uranyl nitrate hexahydrate was obtained from the Centre for Radiochemistry Research (Manchester) isotopes stocks. The complexes $\left[\mathrm{UO}_{2}\right.$ (salophen)(L)], [UO ${ }_{2}$ (salen) $\left.(\mathrm{L})\right](\mathrm{L}=$ py, DMSO, DMF, TPPO) and $\left[\mathrm{Zn}\left(\mathrm{salmnt}^{\left(\mathrm{Et}_{2} \mathrm{~N}\right)_{2}}\right)\right]$ were synthesized as previously described $^{5,6,19,20,22,40}$ and relevant solution NMR and vibrational spectroscopic data of these compounds that have not been previously reported are presented in the ESI. $\dagger$

2,3-Bis[(4-diethylamino-2-hydroxybenzylidene)amino]but-2enedinitrile.DCM (salmnt ${ }^{\left(\mathrm{Et}_{2} \mathrm{~N}\right)_{2}} \mathrm{H}_{2} \cdot \mathrm{DCM}$ ). The compound was synthesized as previously described ${ }^{19}$ Crystals suitable for single crystal X-ray diffraction were obtained from vapour diffusion of a solution of salmnt ${ }^{\left(\mathrm{Et}_{2} \mathrm{~N}_{2}\right.} \mathrm{H}_{2}$ in DCM with hexane. Analysis: calc. for $\mathrm{C}_{26} \mathrm{H}_{30} \mathrm{~N}_{6} \mathrm{O}_{2} \cdot \mathrm{CH}_{2} \mathrm{Cl}_{2}$ : C, 59.67; H, 5.35; N, 16.06\%. Found: $\mathrm{C}$, $60.15 ; \mathrm{H}, 5.50 ; \mathrm{N}, 16.26 \% .{ }^{1} \mathrm{H}$ NMR $\left(\mathrm{CD}_{2} \mathrm{Cl}_{2}\right): \delta_{\mathrm{H}} 1.24(\mathrm{t}, J=$ $\left.7.2 \mathrm{~Hz}, 12 \mathrm{H},-\mathrm{CH}_{3}\right) ; 3.45\left(\mathrm{q}, J=7.2 \mathrm{~Hz}, 8 \mathrm{H},-\mathrm{CH}_{2}-\right) ; 6.23\left(\mathrm{~d}, J^{\prime \prime}=\right.$ $2.4 \mathrm{~Hz}, 2 \mathrm{H}, \mathrm{Ph}-\mathrm{H}) ; 6.36\left(\mathrm{dd}, J^{\prime}=9.2 \mathrm{~Hz}, J^{\prime \prime}=2.4 \mathrm{~Hz}, 2 \mathrm{H}, \mathrm{Ph}-\mathrm{H}\right)$; $7.24\left(\mathrm{~d}, J^{\prime}=9.2 \mathrm{~Hz}, 2 \mathrm{H}, \mathrm{Ph}-\mathrm{H}\right) ; 8.48(\mathrm{~s}, 2 \mathrm{H}, \mathrm{HC}=\mathrm{N}) ; 12.75(\mathrm{~s}$, $2 \mathrm{H}, \mathrm{OH})$ ppm. ${ }^{13} \mathrm{C} \mathrm{NMR}\left(\mathrm{CD}_{2} \mathrm{Cl}_{2}\right): \delta_{\mathrm{C}} 12.9\left(-\mathrm{CH}_{3}\right), 45.4\left(-\mathrm{CH}_{2}-\right.$ ); 97.7, 106.3, $135.9(\mathrm{Ph}-\mathrm{H})$; 109.7, $113.2(\mathrm{Ph}) ; 122.3(=\mathrm{C}-\mathrm{N})$; $154.4(-\mathrm{C} \equiv \mathrm{N}) ; 162.5(\mathrm{CH}=\mathrm{N}) ; 164.7(\mathrm{Ph}-\mathrm{O}) \mathrm{ppm}$. UV-visible spectrum (DCM) $\left[\lambda_{\max } / \mathrm{nm}\left(\varepsilon_{\max } / \mathrm{L} \mathrm{mol}^{-1} \mathrm{~cm}^{-1}\right)\right]: 378$ (28900), 436 (23500), 568 (92800). ESI-MS (+ve ion): $m / z 306\left(\mathrm{C}_{15} \mathrm{H}_{17} \mathrm{~N}_{5} \mathrm{O}+\right.$ $\left.\mathrm{Na}^{+}\right)$. ESI-MS (-ve ion): $m / z 282\left(\mathrm{C}_{15} \mathrm{H}_{17} \mathrm{~N}_{5} \mathrm{O}-\mathrm{H}^{+}\right)$. IR spectrum (solid): 2208 (w, C $=\mathrm{N}) ; 1622(\mathrm{~s}, \mathrm{C}=\mathrm{N}) ; 1560$ (m, C=C); 1517 (s, $\mathrm{C}=\mathrm{C}) \mathrm{cm}^{-1}$. Raman spectrum (solid): $2210(\mathrm{w}, \mathrm{C} \equiv \mathrm{N}) ; 1566(\mathrm{w}$, $\mathrm{C}=\mathrm{C}) ; 1531(\mathrm{~s}, \mathrm{C}=\mathrm{C}) ; 1511(\mathrm{~m}, \mathrm{C}=\mathrm{C}) \mathrm{cm}^{-1}$.

$\left[\mathrm{UO}_{2}\left(\mathrm{salmnt}^{\left(\mathrm{Et}_{2} \mathrm{~N}\right)_{2}}\right)\left(\mathrm{H}_{2} \mathrm{O}\right)\right] \cdot\left(\mathrm{CH}_{3} \mathrm{CH}_{2}\right)_{2} \mathrm{O}\left(\mathbf{1} \cdot\left(\mathrm{CH}_{3} \mathrm{CH}_{2}\right)_{2} \mathrm{O}\right)$. A solution of $\mathrm{UO}_{2}\left(\mathrm{NO}_{2}\right)_{3} \cdot 6 \mathrm{H}_{2} \mathrm{O}(0.20 \mathrm{~g}, 0.4 \mathrm{mmol})$ in methanol $(20 \mathrm{~mL})$ was added dropwise to a methanol solution $(100 \mathrm{~mL})$ of salmnt $\mathrm{Et}_{2} \mathrm{~N}_{2} \mathrm{H}_{2}(0.18 \mathrm{~g}, 0.4 \mathrm{mmol})$ with stirring. The colour changed immediately from pink to dark purple. The mixture was heated to $60^{\circ} \mathrm{C}$ and stirred for approximately $3 \mathrm{~h}$. The mixture was left in the fridge overnight yielding a black precipitate. The mixture was filtered, and the isolated precipitate was dissolved in DCM $(100 \mathrm{~mL})$, filtered and the solvent removed under reduced pressure. The dark purple residue was dissolved in DCM $(25 \mathrm{~mL})$, filtered and allowed to vapour diffuse with diethyl ether at $4{ }^{\circ} \mathrm{C}$. Dark purple block-like crystals were obtained after several days $(0.07 \mathrm{~g}$, $21 \%$ ). Analysis: calc. for $\mathrm{C}_{26} \mathrm{H}_{28} \mathrm{~N}_{6} \mathrm{O}_{5} \mathrm{U}_{2} \mathrm{C}_{4} \mathrm{H}_{10} \mathrm{O}: \mathrm{C}, 44.0 ; \mathrm{H}, 4.92$; $\mathrm{N}, 10.26 ; \mathrm{U}, 29.07 \%$. Found C, 42.94; H, 4.72; N, 10.27; U, $28.81 \%$. ${ }^{1} \mathrm{H}$ NMR $\left(\mathrm{d}_{2}\right.$-DCM-impure, see Results and discussion for details): $\delta_{\mathrm{H}} 1.11\left(\mathrm{br}, 12 \mathrm{H},-\mathrm{CH}_{3}\right) ; 1.62\left(\mathrm{br}, \mathrm{H}_{2} \mathrm{O}\right) ; 3.35$ (br, $8 \mathrm{H},-\mathrm{CH}_{2}-$ ); 6.41 (br, 4H, $\mathrm{Ph}-\mathrm{H}$ ); 7.55 (br, 2H, Ph-H), 9.22 (br, $2 \mathrm{H}, \mathrm{HC}=\mathrm{N}$ ) ppm. IR spectrum (solid): $2208(\mathrm{~m}, \mathrm{C} \equiv \mathrm{N}) ; 1601(\mathrm{~s}$, $\mathrm{C}=\mathrm{N}) ; 1547(\mathrm{~s}, \mathrm{C}=\mathrm{C}) ; 1515(\mathrm{~m}, \mathrm{C}=\mathrm{C}) ; 898\left(\mathrm{~s}, v_{3} \mathrm{O}=\mathrm{U}=\mathrm{O}\right) ; 826$ (m, $\left.v_{1} \mathrm{O}=\mathrm{U}=\mathrm{O}\right) \mathrm{cm}^{-1}$. Raman spectrum (solid): $2212(\mathrm{w}, \mathrm{C} \equiv \mathrm{N})$; $1610(\mathrm{w}, \mathrm{C}=\mathrm{N}) ; 1545(\mathrm{~s}, \mathrm{C}=\mathrm{C}) ; 826\left(\mathrm{vw}, v_{1} \mathrm{O}=\mathrm{U}=\mathrm{O}\right) \mathrm{cm}^{-1}$.

$\left[\mathrm{UO}_{2}\left(\mathrm{salmnt}^{\left(\mathrm{Et}_{2} \mathrm{~N}\right)_{2}}\right)(\mathrm{py})\right](2)$. The crude precipitate of $\mathbf{1}$, prepared as described above, was dissolved in py $(60 \mathrm{~mL})$ and left to evaporate yielding dark purple crystals $(0.17 \mathrm{~g}, 53 \%)$. Two crystal forms of the same molecular composition were isolated (2a and 2b). Analysis: calc. for $\mathrm{C}_{31} \mathrm{H}_{33} \mathrm{~N}_{7} \mathrm{O}_{4} \mathrm{U}$ : C, 46.19; $\mathrm{H}, 4.13 ; \mathrm{N}, 12.17 \%$. Found C, 46.88; H, 4.09; N, $11.86 \%{ }^{1} \mathrm{H}$ NMR (d $\mathrm{d}_{2}$-DCM): $\delta_{\mathrm{H}} 1.27$ (t, $\left.J=6.4 \mathrm{~Hz}, 12 \mathrm{H},-\mathrm{CH}_{3}\right) ; 3.50\left(\mathrm{q}, J=6.4 \mathrm{~Hz}, 8 \mathrm{H},-\mathrm{CH}_{2}-\right.$ ); 6.11 (s, 2H, Ph-H), 6.34, 7.43 (d, $J=9.2 \mathrm{~Hz}, 2 \mathrm{H}, \mathrm{Ph}-\mathrm{H}) ; 7.78$ (s br, $\left.2 \mathrm{H}, \mathrm{Ph}_{(p y)}-\mathrm{H}\right) ; 8.09$ (s br, $\left.1 \mathrm{H}, \mathrm{Ph}_{(p y)}-\mathrm{H}\right) ; 9.15(\mathrm{~s}, 2 \mathrm{H}, \mathrm{HC}=\mathrm{N})$; 9.62 (s br, $\left.2 \mathrm{H}, \mathrm{N}-\mathrm{Ph}_{(p y)}-\mathrm{H}\right)$ ppm. ${ }^{1} \mathrm{H}$ NMR $\left(\mathrm{d}_{5}-\mathrm{py}\right): \delta_{\mathrm{H}} 1.05(\mathrm{t}, J=$ $\left.7.2 \mathrm{~Hz}, 12 \mathrm{H},-\mathrm{CH}_{3}\right) ; 3.30\left(\mathrm{q}, J=7.2 \mathrm{~Hz}, 8 \mathrm{H},-\mathrm{CH}_{2}-\right)$; 6.35-6.38 (m, 4H, Ph-H), 7.50 (d, $J=8.8 \mathrm{~Hz}, 2 \mathrm{H}, \mathrm{Ph}-\mathrm{H}) ; 7.19,7.56,8.70$ $\left(\mathrm{s}, \mathrm{Ph}_{(p y)}-\mathrm{H}\right) ; 9.40(\mathrm{~s}, 2 \mathrm{H}, \mathrm{HC}=\mathrm{N}) \mathrm{ppm} .{ }^{13} \mathrm{C} \mathrm{NMR}\left(\mathrm{d}_{2}-\mathrm{DCM}\right): \delta_{\mathrm{C}}$ $13.1\left(-\mathrm{CH}_{3}\right) ; 45.6\left(-\mathrm{CH}_{2}-\right) ; 99.8,107.1,139.0,(\mathrm{Ph}-\mathrm{H}) ; 114.7,115.0$ $(\mathrm{Ph}) ; 125.4,139.1\left(\mathrm{Ph}_{(p y)}-\mathrm{H}\right) ; 126.9(=\mathrm{C}-\mathrm{N}) ; 151.9\left(\mathrm{Ph}_{(p y)}-\mathrm{N}\right) ; 157.3$ $(-\mathrm{C} \equiv \mathrm{N}) ; 162.5(\mathrm{CH}=\mathrm{N}) ; 173.3(\mathrm{Ph}-\mathrm{O}) \mathrm{ppm} .{ }^{13} \mathrm{C} \mathrm{NMR}\left(\mathrm{d}_{5}-\mathrm{py}\right)$ : $\delta_{\mathrm{C}} 13.4\left(-\mathrm{CH}_{3}\right) ; 45.6\left(-\mathrm{CH}_{2}-\right) ; 100.6,107.6,139.7,(\mathrm{Ph}-\mathrm{H}) ; 115.5$, 
$116.1(\mathrm{Ph}) ; 124.3,136.3\left(\mathrm{Ph}_{(p y)}-\mathrm{H}\right) ; 127.5(=\mathrm{C}-\mathrm{N}) ; 150.7\left(\mathrm{Ph}_{(p y)}-\right.$ $\mathrm{N}) ; 157.7(-\mathrm{C} \equiv \mathrm{N}) ; 163.1(\mathrm{CH}=\mathrm{N}) ; 174.5(\mathrm{Ph}-\mathrm{O}) \mathrm{ppm}$. UV-visible spectrum (DCM) $\left[\lambda_{\max } / \mathrm{nm}\left(\varepsilon_{\max } / \mathrm{L} \mathrm{mol}^{-1} \mathrm{~cm}^{-1}\right)\right]: 379$ (21100), 436 (22400), 579 (40700). UV-visible spectrum (py) $\left[\lambda_{\max } / \mathrm{nm}\left(\varepsilon_{\max } / \mathrm{L}\right.\right.$ $\left.\mathrm{mol}^{-1} \mathrm{~cm}^{-1}\right)$ ]: 380 (24000), 435 (28000), 595 (51000). IR spectrum (solid): $2210(\mathrm{~m}, \mathrm{C} \equiv \mathrm{N}) ; 1605(\mathrm{~s}, \mathrm{C}=\mathrm{N}) ; 1552$ (s, C=C); $1517(\mathrm{~m}$, $\mathrm{C}=\mathrm{C}) ; 893\left(\mathrm{~s}, v_{3} \mathrm{O}=\mathrm{U}=\mathrm{O}\right) ; 818\left(\mathrm{~m}, v_{1} \mathrm{O}=\mathrm{U}=\mathrm{O}\right) \mathrm{cm}^{-1}$. Raman spectrum (solid): $2212(\mathrm{w}, \mathrm{C} \equiv \mathrm{N}) ; 1611(\mathrm{w}, \mathrm{C}=\mathrm{N}) ; 1548(\mathrm{~s}, \mathrm{C}=\mathrm{C})$; $823\left(\mathrm{vw}, v_{1} \mathrm{O}=\mathrm{U}=\mathrm{O}\right) \mathrm{cm}^{-1}$.

$\left[\mathrm{UO}_{2}\left(\mathrm{salmnt}^{\left(\mathrm{Et}_{2} \mathrm{~N}\right)_{2}}\right)(\mathrm{DMSO})\right]$ (3). The crude precipitate of $\mathbf{1}$, prepared as described above, was dissolved in DMSO $(50 \mathrm{~mL})$, filtered and left to stand. After several days dark purple crystals were obtained $(0.05 \mathrm{~g}, 16 \%)$. Analysis: calc. for $\mathrm{C}_{28} \mathrm{H}_{34} \mathrm{~N}_{6} \mathrm{O}_{5} \mathrm{SU}$ : C, 41.79; H, 4.26; N, 10.44; S, 3.98; U, 29.58\%. Found C, 42.51; $\mathrm{H}, 4.23 ; \mathrm{N}, 10.35 ; \mathrm{S}, 3.91 ; \mathrm{U}, 29.63 \% .{ }^{1} \mathrm{H} \mathrm{NMR}\left(\mathrm{CD}_{2} \mathrm{Cl}_{2}\right): \delta_{\mathrm{H}}$ $1.30\left(\mathrm{t}, J=7.0 \mathrm{~Hz}, 12 \mathrm{H},-\mathrm{CH}_{3}\right) ; 3.13\left(\mathrm{~s}, 6 \mathrm{H},-\mathrm{CH}_{3(D M S O)}\right) ; 3.53$ $\left(\mathrm{q}, J=7.0 \mathrm{~Hz}, 8 \mathrm{H},-\mathrm{CH}_{2}-\right) ; 6.22(\mathrm{~s}, 2 \mathrm{H}, \mathrm{Ph}-\mathrm{H}) ; 6.33,7.41(\mathrm{~d}$, $J=9.2 \mathrm{~Hz}, 2 \mathrm{H}, \mathrm{Ph}-\mathrm{H}) ; 9.12(\mathrm{~s}, 2 \mathrm{H}, \mathrm{CH}=\mathrm{N}) \mathrm{ppm} .{ }^{1} \mathrm{H}$ NMR $\left(\mathrm{d}_{6}\right.$-DMSO): $\delta_{\mathrm{H}} 1.24\left(\mathrm{t}, J=7.2 \mathrm{~Hz}, 12 \mathrm{H},-\mathrm{CH}_{3}\right) ; 2.55(\mathrm{~s}, 6 \mathrm{H},-$ $\left.\mathrm{CH}_{3(D M S O)}\right) ; 3.56\left(\mathrm{q}, J=7.2 \mathrm{~Hz}, 8 \mathrm{H},-\mathrm{CH}_{2}-\right) ; 6.12(\mathrm{~d}, J=2.4 \mathrm{~Hz}$, $2 \mathrm{H}, \mathrm{Ph}-\mathrm{H}) ; 6.40\left(\mathrm{dd}, J^{\prime}=9.2 \mathrm{~Hz}, J^{\prime \prime}=2.4 \mathrm{~Hz}, 2 \mathrm{H}, \mathrm{Ph}-\mathrm{H}\right)$; $7.55(\mathrm{~d}, J=9.2 \mathrm{~Hz}, 2 \mathrm{H}, \mathrm{Ph}-\mathrm{H}) ; 9.07(\mathrm{~s}, 2 \mathrm{H}, \mathrm{CH}=\mathrm{N}) \mathrm{ppm} .{ }^{13} \mathrm{C}$ $\mathrm{NMR}(\mathrm{DCM}): \delta_{\mathrm{C}} 13.2\left(-\mathrm{CH}_{3}\right) ; 39.7\left(-\mathrm{CH}_{3(D M S O)}\right) ; 45.5\left(-\mathrm{CH}_{2}-\right)$; $100.1,106.9,139.0(\mathrm{Ph}-\mathrm{H}) ; 127.1(=\mathrm{C}-\mathrm{N}) ; 157.3(-\mathrm{C} \equiv \mathrm{N}) ; 162.6$ $(\mathrm{CH}=\mathrm{N}) ; 173.7(\mathrm{Ph}-\mathrm{O}) \mathrm{ppm} .{ }^{13} \mathrm{C} \mathrm{NMR}\left(\mathrm{d}_{6}-\mathrm{DMSO}\right): \delta_{\mathrm{C}} 12.9$ $\left(-\mathrm{CH}_{3}\right) ; 40.4\left(-\mathrm{CH}_{3(D M S O}\right) ; 44.5\left(-\mathrm{CH}_{2}-\right) ; 99.1,106.4,138.6(\mathrm{Ph}-$ $\mathrm{H}) ; 114.5,114.6(\mathrm{Ph}) ; 125.7(=\mathrm{C}-\mathrm{N}) ; 156.3(-\mathrm{C} \equiv \mathrm{N}) ; 161.5$ $(\mathrm{CH}=\mathrm{N}) ; 173.0(\mathrm{Ph}-\mathrm{O})$ ppm. UV-visible spectrum (DCM) $\left[\lambda_{\max } / \mathrm{nm} \quad\left(\varepsilon_{\max } / \mathrm{L} \quad \mathrm{mol}^{-1} \quad \mathrm{~cm}^{-1}\right)\right]: 379$ (48700), 434 (53100), 583 (93600). UV-visible spectrum (DMSO) $\left[\lambda_{\max } / \mathrm{nm}\left(\varepsilon_{\max } / \mathrm{L}\right.\right.$ $\left.\mathrm{mol}^{-1} \mathrm{~cm}^{-1}\right)$ ]: 276 (19000), 381 (18000), 435 (21000), 598 (41000). IR spectrum (solid): $2211(\mathrm{~m}, \mathrm{C} \equiv \mathrm{N}) ; 1605(\mathrm{~s}, \mathrm{C}=\mathrm{N}) ; 1554$ (s, $\mathrm{C}=\mathrm{C}) ; 1513(\mathrm{~m}, \mathrm{C}=\mathrm{C}) ; 1076(\mathrm{~s}, \mathrm{~S}=\mathrm{O}) ; 885\left(\mathrm{~s}, v_{3} \mathrm{O}=\mathrm{U}=\mathrm{O}\right), 820$ (m, $\left.v_{1} \mathrm{O}=\mathrm{U}=\mathrm{O}\right) \mathrm{cm}^{-1}$. Raman spectrum (solid): $2219(\mathrm{w}, \mathrm{C} \equiv \mathrm{N})$; $1612(\mathrm{w}, \mathrm{C}=\mathrm{N}) ; 1550(\mathrm{~s}, \mathrm{C}=\mathrm{C}) ; 828\left(\mathrm{vw}, v_{1} \mathrm{O}=\mathrm{U}=\mathrm{O}\right) \mathrm{cm}^{-1}$.

$\left[\mathrm{UO}_{2}\left(\mathrm{salmnt}^{\left(\mathrm{Et}_{2} \mathrm{~N}\right)_{2}}\right)(\mathrm{DMF})\right]$ (4). The crude precipitate of $\mathbf{1}$, prepared as described above, was dissolved in DMF $(50 \mathrm{~mL})$, filtered and left to stand. After several days dark purple crystals were obtained $(0.18 \mathrm{~g}, 56 \%)$. Analysis: calc. for $\mathrm{C}_{29} \mathrm{H}_{35} \mathrm{~N}_{7} \mathrm{O}_{5} \mathrm{U}: \mathrm{C}$, 43.55; H, 4.41; N, 12.26; U, 29.77\%. Found C, 43.67; H, 4.37; N, 12.04; U, 29.36\%. ${ }^{1} \mathrm{H}$ NMR (d $\mathrm{d}_{2}$-DCM): $\delta_{\mathrm{H}} 1.25(\mathrm{t}, J=6.8 \mathrm{~Hz}$, $\left.12 \mathrm{H},-\mathrm{CH}_{3}\right) ; 3.19,3.27\left(\mathrm{~s}, 3 \mathrm{H},-\mathrm{CH}_{3(D M F)}\right) ; 3.48$ (q, $J=6.8 \mathrm{~Hz}, 8 \mathrm{H}$, $\left.-\mathrm{CH}_{2}-\right) ; 6.22(\mathrm{~s}, 2 \mathrm{H}, \mathrm{Ph}-\mathrm{H}) ; 6.34,7.42(\mathrm{~d}, J=8.4 \mathrm{~Hz}, 2 \mathrm{H}, \mathrm{Ph}-$ $\mathrm{H}) ; 8.81$ (s br, $1 \mathrm{H}, \mathrm{CH}=\mathrm{O}) ; 9.14(\mathrm{~s}, 2 \mathrm{H}, \mathrm{CH}=\mathrm{N}) \mathrm{ppm} .{ }^{1} \mathrm{H}$ NMR $\left(\mathrm{d}_{7}-\mathrm{DMF}\right): 1.47\left(\mathrm{t}, J=7.2 \mathrm{~Hz}, 12 \mathrm{H},-\mathrm{CH}_{3}\right) ; 2.98,3.14(\mathrm{~s}, 3 \mathrm{H}$, $\left.-\mathrm{CH}_{3(D M F)}\right) ; 3.81$ (q, $\left.J=7.2 \mathrm{~Hz}, 8 \mathrm{H},-\mathrm{CH}_{2}-\right) ; 6.43(\mathrm{~d}, J=2.0 \mathrm{~Hz}$, $2 \mathrm{H}, \mathrm{Ph}-\mathrm{H}) ; 6.67\left(\mathrm{dd}, J^{\prime}=9.2 \mathrm{~Hz}, J^{\prime \prime}=2.0 \mathrm{~Hz}, 2 \mathrm{H}, \mathrm{Ph}-\mathrm{H}\right) ; 7.83$ $(\mathrm{d}, J=9.2 \mathrm{~Hz}, 2 \mathrm{H}, \mathrm{Ph}-\mathrm{H}) ; 9.38(\mathrm{~s}, 2 \mathrm{H}, \mathrm{CH}=\mathrm{N}) \mathrm{ppm} .{ }^{13} \mathrm{C} \mathrm{NMR}$ $\left(\mathrm{d}_{2}-\mathrm{DCM}\right): \delta_{\mathrm{C}} 13.1\left(-\mathrm{CH}_{3}\right) ; 32.6,37.6\left(-\mathrm{CH}_{3(D M F)}\right) ; 45.5\left(-\mathrm{CH}_{2}-\right)$; $100.1,106.9,138.9(\mathrm{Ph}-\mathrm{H}) ; 114.7,115.1(\mathrm{Ph}) ; 126.9(=\mathrm{C}-\mathrm{N}) ; 157.2$ $(-\mathrm{C} \equiv \mathrm{N}) ; 162.5(\mathrm{CH}=\mathrm{N}) ; 165.9\left(\mathrm{br}, \mathrm{CH}=\mathrm{O}_{(D M F)}\right) ; 173.6(\mathrm{Ph}-\mathrm{O})$ ppm. ${ }^{13} \mathrm{C} \mathrm{NMR}\left(\mathrm{d}_{7}-\mathrm{DMF}\right): \delta_{\mathrm{C}} 12.8\left(-\mathrm{CH}_{3}\right) ; 30.5,35.6\left(-\mathrm{CH}_{3(D M F)}\right)$; $44.9\left(-\mathrm{CH}_{2}-\right)$; 99.9, 106.8, $139.0(\mathrm{Ph}-\mathrm{H}) ; 114.8,115.4(\mathrm{Ph}) ; 126.4$ $(=\mathrm{C}-\mathrm{N}) ; 157.1(-\mathrm{C} \equiv \mathrm{N}) ; 162.1\left(\mathrm{CH}=\mathrm{O}_{(D M F)}\right) ; 162.5(\mathrm{CH}=\mathrm{N})$; $173.9(\mathrm{Ph}-\mathrm{O}) \mathrm{ppm}$. UV-visible spectrum (DCM) $\left[\lambda_{\max } / \mathrm{nm}\left(\varepsilon_{\max } / \mathrm{L}\right.\right.$ $\left.\mathrm{mol}^{-1} \mathrm{~cm}^{-1}\right)$ ]: 380 (28200), 436 (29400), 574 (54000). UV-visible spectrum (DMF) $\left[\lambda_{\max } / \mathrm{nm}\left(\varepsilon_{\max } / \mathrm{L} \mathrm{mol}^{-1} \mathrm{~cm}^{-1}\right)\right]: 282$ (34000), 378 (52000), 431 (61000), 594 (120000). IR spectrum (solid): 2204 (m, $\mathrm{C} \equiv \mathrm{N}) ; 1653\left(\mathrm{~s}, \mathrm{C}=\mathrm{O}_{(D M F)}\right) ; 1613(\mathrm{~s}, \mathrm{C}=\mathrm{N}) ; 1563(\mathrm{~s}, \mathrm{C}=\mathrm{C}) ; 899$ (s, $\left.v_{3} \mathrm{O}=\mathrm{U}=\mathrm{O}\right) ; 818\left(\mathrm{~m}, v_{1} \mathrm{O}=\mathrm{U}=\mathrm{O}\right) \mathrm{cm}^{-1}$. Raman spectrum (solid): 2209 (w, C $\equiv \mathrm{N}) ; 1615(\mathrm{w}, \mathrm{C}=\mathrm{N}) ; 1559$ (s, C=C); 819 (w, $\left.v_{1} \mathrm{O}=\mathrm{U}=\mathrm{O}\right) \mathrm{cm}^{-1}$.

$\left[\mathrm{UO}_{2}\left(\mathrm{salmnt}^{\left(\mathrm{Et}_{2} \mathrm{~N}\right)_{2}}\right)(\mathrm{TPPO})\right] \cdot \mathrm{H}_{2} \mathrm{O}\left(\mathbf{5} \cdot \mathrm{H}_{2} \mathrm{O}\right)$. The crude precipitate of $\mathbf{1}$, prepared as described above, was dissolved in DCM $(50 \mathrm{~mL})$, filtered and a solution of TPPO $(0.04 \mathrm{~g})$ in DCM $(5 \mathrm{~mL})$ was added to the filtrate with stirring. The solution was stirred for one hour. The reaction mixture was allowed to vapour diffuse with diethyl ether at $\sim 4{ }^{\circ} \mathrm{C}$. After several days, dark purple crystals were obtained ( $0.18 \mathrm{~g}, 44 \%)$. Analysis: calc. for $\mathrm{C}_{44} \mathrm{H}_{43} \mathrm{~N}_{6} \mathrm{O}_{5} \mathrm{PU} \cdot \mathrm{H}_{2} \mathrm{O}: \mathrm{C}$, 51.66; H, 4.43; N, 8.22; P, 3.03; U, 23.27\%. Found C, 52.48; H, $4.31 ; \mathrm{N}, 8.37 ; \mathrm{P}, 2.91 ; \mathrm{U}, 22.74 \% .{ }^{1} \mathrm{H} \mathrm{NMR}\left(\mathrm{d}_{2}-\mathrm{DCM}\right): \delta_{\mathrm{H}} 1.15(\mathrm{t}$, $\left.J=7.2 \mathrm{~Hz}, 12 \mathrm{H},-\mathrm{CH}_{3}\right) ; 3.34\left(\mathrm{q}, J=7.2 \mathrm{~Hz}, 8 \mathrm{H},-\mathrm{CH}_{2}-\right) ; 5.72$ (s, 2H, Ph-H); 6.27 (dd, $\left.J^{\prime}=9.2 \mathrm{~Hz}, J^{\prime \prime}=2.4 \mathrm{~Hz}, 2 \mathrm{H}, \mathrm{Ph}-\mathrm{H}\right)$; 7.37 (d, $\left.J^{\prime}=9.2 \mathrm{~Hz}, 2 \mathrm{H}, \mathrm{Ph}-\mathrm{H}\right) ; 7.38-8.13\left(\mathrm{~m}, 15 \mathrm{H}, \mathrm{Ph}_{(T P P O)}-\mathrm{H}\right)$; $9.12(\mathrm{~s}, 2 \mathrm{H}, \mathrm{CH}=\mathrm{N}) \mathrm{ppm} .{ }^{13} \mathrm{C} \mathrm{NMR}\left(\mathrm{d}_{2}-\mathrm{DCM}\right): \delta_{\mathrm{C}} 13.1\left(\mathrm{CH}_{3}\right)$; $45.2\left(\mathrm{CH}_{2}\right)$; 100.2, 106.6, $138.7(\mathrm{Ph}-\mathrm{H}) ; 115.0,115.4(\mathrm{Ph}) ; 127.2$ $(=\mathrm{C}-\mathrm{N}) ; 129.2,129.3,133.3,133.4,133.5\left(\mathrm{Ph}_{(T P P O)}-\mathrm{H}\right) ; 130.4(\mathrm{~d}$, $\left.J_{13 \mathrm{C}_{-}{ }^{31} \mathrm{P}}=106 \mathrm{~Hz}, \mathrm{Ph}_{(T P P O)}-\mathrm{P}\right) ; 156.9(-\mathrm{C} \equiv \mathrm{N}) ; 162.6(\mathrm{CH}=\mathrm{N})$; $174.1(\mathrm{Ph}-\mathrm{O})$ ppm. ${ }^{31} \mathrm{P} \mathrm{NMR}\left(\mathrm{CD}_{2} \mathrm{Cl}_{2}\right): \delta_{\mathrm{P}} 43.4 \mathrm{ppm}$. UV-visible spectrum (DCM) $\left[\lambda_{\max } / \mathrm{nm}\left(\varepsilon_{\max } / \mathrm{L} \mathrm{mol}^{-1} \mathrm{~cm}^{-1}\right)\right]: 377$ (34300), 432 (41400), 584 (79600). IR spectrum (solid): 2208 (m, C $\equiv \mathrm{N}) ; 1606$ (s, $\mathrm{C}=\mathrm{N}) ; 1558(\mathrm{~s}, \mathrm{C}=\mathrm{C}) ; 1093(\mathrm{~s}, \mathrm{P}=\mathrm{O}) ; 888\left(\mathrm{~s}, v_{3} \mathrm{O}=\mathrm{U}=\mathrm{O}\right), 818$ $\left(\mathrm{m}, v_{1} \mathrm{O}=\mathrm{U}=\mathrm{O}\right) \mathrm{cm}^{-1}$. Raman spectrum (solid): $2210(\mathrm{w}, \mathrm{C} \equiv \mathrm{N})$; $1612(\mathrm{w}, \mathrm{C}=\mathrm{N}) ; 1552(\mathrm{~s}, \mathrm{C}=\mathrm{C}) ; 820\left(\mathrm{vw}, v_{1} \mathrm{O}=\mathrm{U}=\mathrm{O}\right) \mathrm{cm}^{-1}$.

$\left[\mathrm{UO}_{2}(\right.$ salophen)(py)]. The compound was synthesized as previously described. ${ }^{22}$ Crystals suitable for X-ray crystallography were obtained by slow evaporation from a dichloromethane solution.

$\left[\mathrm{UO}_{2}\right.$ (salen)(TPPO)]-TPPO. The compound was synthesized as previously described. ${ }^{22}$ Crystals suitable for X-ray crystallography were obtained by vapour diffusion of a dichloromethane solution with diethyl ether at $4{ }^{\circ} \mathrm{C}$. Analysis: calc. for $\mathrm{C}_{34} \mathrm{H}_{29} \mathrm{~N}_{2} \mathrm{O}_{5}$ PU.C $\mathrm{C}_{18} \mathrm{H}_{15} \mathrm{OP}: \mathrm{C}, 57.15 ; \mathrm{H}, 4.06 ; \mathrm{N}, 2.56$; P, 5.67; $\mathrm{U}, 21.78 \%$. Found $\mathrm{C}, 56.90 ; \mathrm{H}, 3.74 ; \mathrm{N}, 2.46 ; \mathrm{P}, 5.73$; U, $21.97 \%$.

\section{Electrochemical measurements}

Cyclic voltammetry was performed using a three electrode system consisting of a Pt working electrode, a Pt auxillary electrode and a Ag wire quasi-reference electrode purchased from BASi. Potentials were controlled using a PAR EG\&G 263A potentiostat operated by model 250 Research Electrochemistry Software (M270) version 4.41. Studies of complexes $\mathbf{1 - 5}$, [ $\mathrm{UO}_{2}$ (salophen)(TPPO)], $\left[\mathrm{UO}_{2}\right.$ (salen)(TPPO)] and salmnt ${ }^{\left(\mathrm{Et}{ }_{2} \mathrm{~N}_{2}\right.} \mathrm{H}_{2}$ were conducted in DCM solutions with a complex/ligand concentration of $5 \mathrm{mM}$ and $0.1 \mathrm{M}$ $\mathrm{Bu}_{4} \mathrm{NPF}_{6}$ as the inert electrolyte. Electrochemical measurements of complexes 2-4, [ $\mathrm{UO}_{2}($ salophen $\left.)(\mathrm{L})\right]$ and $\left[\mathrm{UO}_{2}(\right.$ salen $\left.)(\mathrm{L})\right](\mathrm{L}=$ py, DMSO, DMF) were performed under the same conditions, but the solvent was the same as that of the monodentate ligand. All voltammetric data were obtained both with and without ferrocene present in solution, so potentials were internally referenced to the $\mathrm{Fc}^{+} / \mathrm{Fc}$ redox couple where possible, and externally referenced otherwise. Solutions were degassed with dinitrogen for at least ten minutes before measurements were obtained. All voltammograms are corrected for internal resistance using the programme CONDECON (Version 7.0). 
Table 7 Crystal data

\begin{tabular}{|c|c|c|c|c|c|c|c|c|c|}
\hline & $\begin{array}{l}\text { salmnt } \\
\mathrm{H}_{2} \cdot \mathrm{CH}_{2} \mathrm{Cl}_{2} \mathrm{Cl}_{2}\end{array}$ & 1. $\left(\mathrm{C}_{2} \mathrm{H}_{5}\right)_{2} \mathrm{O}$ & $2 a$ & $2 \mathbf{b}$ & 3 & 4 & $5 \cdot \mathrm{H}_{2} \mathrm{O}$ & $\begin{array}{l}{\left[\mathrm{UO}_{2} \text { (salophen) }\right.} \\
\text { (py)] }\end{array}$ & $\begin{array}{l}{\left[\mathrm{UO}_{2} \text { (salen) }\right.} \\
\text { (TPPO)].TPPO }\end{array}$ \\
\hline Empirical & $\mathrm{C}_{27} \mathrm{H}_{32} \mathrm{Cl}_{2-}$ & $\mathrm{C}_{30} \mathrm{H}_{40} \mathrm{~N}_{6^{-}}$ & $\mathrm{C}_{62} \mathrm{H}_{66} \mathrm{~N}_{14^{-}}$ & $\mathrm{C}_{31} \mathrm{H}_{33} \mathrm{~N}_{7-}$ & $\mathrm{C}_{28} \mathrm{H}_{34} \mathrm{~N}_{6^{-}}$ & $\mathrm{C}_{29} \mathrm{H}_{35} \mathrm{~N}_{7^{-}}$ & $\mathrm{C}_{44} \mathrm{H}_{45} \mathrm{~N}_{6}-$ & $\mathrm{C}_{25} \mathrm{H}_{19} \mathrm{~N}_{3^{-}}$ & $\mathrm{C}_{52} \mathrm{H}_{44} \mathrm{~N}_{2-}$ \\
\hline$M_{\mathrm{r}}$ & 543.49 & 818.71 & 1611.35 & 805.67 & 804.70 & 799.67 & 1022.86 & 663.46 & 1092.86 \\
\hline $\begin{array}{l}\text { Crystal } \\
\text { system }\end{array}$ & Monoclinic & Monoclinic & Monoclinic & Triclinic & Triclinic & Monoclinic & Triclinic & Monoclinic & Triclinic \\
\hline Space group & $P 2_{1} / n$ & $P 2_{1} / n$ & $P 2_{1} / n$ & $P-1$ & $P-1$ & $\mathrm{P} 2_{1} / \mathrm{c}$ & $P-1$ & $\mathrm{P} 2{ }_{1} / \mathrm{c}$ & $P-1$ \\
\hline$c / \AA$ & $22.219(5)$ & $20.758(5)$ & $19.211(5)$ & $13.456(5)$ & $12.408(5)$ & $11.064(5)$ & $14.165(5)$ & $14.6513(12)$ & $17.738(5)$ \\
\hline$\alpha /$ deg. & 90 & 90 & 90 & $111.483(5)$ & $63.464(5)$ & 90 & $107.335(5)$ & 90 & $97.947(5)$ \\
\hline$\beta /$ deg. & $96.106(5)$ & $107.496(5)$ & $91.028(5)$ & $91.195(5)$ & $75.586(5)$ & $99.161(5)$ & $105.515(5)$ & $113.8580(10)$ & $92.478(5)$ \\
\hline$\gamma /$ deg. & 90 & 90 & 90 & $105.695(5)$ & $85.808(5)$ & 90 & $90.276(5)$ & 90 & $106.066(5)$ \\
\hline$V / \AA^{3}$ & $2732(2)$ & $3200.9(19)$ & $6158(3)$ & $1567.8(11)$ & $1456.5(11)$ & 2977.9(19) & 2047.9(14) & 2241.1(3) & $2202.6(16)$ \\
\hline $\mathrm{Z}$ & 4 & 4 & 4 & 2 & 2 & 4 & 2 & 4 & 2 \\
\hline$D_{\mathrm{c}} / \mathrm{g} \mathrm{cm}^{-3}$ & 1.321 & 1.699 & 1.738 & 1.707 & 1.835 & 1.784 & 1.659 & 1.966 & 1.648 \\
\hline & $-26 \leq l \leq 26$ & $-25 \leq l \leq 25$ & $-23 \leq l \leq 23$ & $-16 \leq l \leq 16$ & $-14 \leq l \leq 14$ & $-13 \leq l \leq 13$ & $-17 \leq l \leq 17$ & $-17 \leq l \leq 16$ & $-21 \leq l \leq 21$ \\
\hline $\begin{array}{l}\text { Total no. } \\
\text { reflections }\end{array}$ & 19353 & 25120 & 43986 & 11282 & 10565 & 21018 & 14955 & 11560 & 16089 \\
\hline $\begin{array}{l}\text { Unique } \\
\text { reflections }\end{array}$ & 5000 & 6544 & 11235 & 5632 & 5242 & 5309 & 7425 & 4079 & 8060 \\
\hline GOF & 0.878 & 1.062 & 1.035 & 1.028 & 0.966 & 1.052 & 1.020 & 0.947 & 0.924 \\
\hline$R\left(F_{0}\right)$ & 0.0822 & 0.0362 & 0.0476 & 0.0586 & 0.0456 & 0.0722 & 0.0263 & 0.0279 & 0.0392 \\
\hline$R_{\mathrm{w}}$ & 0.1840 & 0.0543 & 0.0748 & 0.0686 & 0.0561 & 0.1207 & 0.0303 & 0.0362 & 0.0568 \\
\hline Largest diff. & 1.351 and & 1.237 and & 1.540 and & 4.080 and & 1.732 and & 1.189 and & 1.263 and & 1.913 and & 1.922 and \\
\hline $\begin{array}{l}\text { peak and } \\
\text { hole } / \mathrm{e} \AA^{-3}\end{array}$ & -0.848 & -0.998 & -1.727 & -3.792 & -3.156 & -2.637 & -0.811 & -0.590 & -1.347 \\
\hline
\end{tabular}

\section{X-Ray crystallography}

Diffraction data for salmnt ${ }^{\left(\mathrm{E}_{2} \mathrm{~N}_{2}\right.} \mathrm{H}_{2} \cdot \mathrm{DCM}$ and complexes $\left[\mathrm{UO}_{2}\left(\mathrm{salmnt}^{\left(\mathrm{Et}_{2} \mathrm{~N}_{2}\right.}\right)\left(\mathrm{H}_{2} \mathrm{O}\right)\right] \cdot\left(\mathrm{CH}_{3} \mathrm{CH}_{2}\right)_{2} \mathrm{O} \quad\left(\mathbf{1} \cdot\left(\mathrm{CH}_{3} \mathrm{CH}_{2}\right)_{2} \mathrm{O}\right)$, $\left[\mathrm{UO}_{2}\left(\mathrm{salmnt}^{\left(\mathrm{Et}_{2} \mathrm{~N}_{2}\right)}\right)(\mathrm{py})\right]$ (2), [UO $\left.{ }_{2}\left(\operatorname{salmnt}^{\left(\mathrm{Et}_{2} \mathrm{~N} / 2\right.}\right)(\mathrm{DMSO})\right]$ (3), $\left[\mathrm{UO}_{2}\left(\mathrm{salmnt}^{\left(\mathrm{Et}_{2} \mathrm{~N}_{2}\right)}\right)(\mathrm{DMF})\right](4),\left[\mathrm{UO}_{2}\left(\mathrm{salmnt}^{\left(\mathrm{E}_{2} \mathrm{~N} / 2\right.}\right)(\mathrm{TPPO})\right] \cdot \mathrm{H}_{2} \mathrm{O}$ $\left(5 \cdot \mathrm{H}_{2} \mathrm{O}\right)$ and $\left[\mathrm{UO}_{2}\right.$ (salophen)(py)] were measured with a Bruker APEX SMART platform CCD at $100 \mathrm{~K}$. Crystal data for all structures are summarized in Table 7. Structures were solved by direct methods using SHELXS97 (1) or SIR92 (all other structures), and refined using SHELXL97..$^{41-43}$ All non-hydrogen atoms not exhibiting disorder were refined anisotropically, while hydrogen atoms were included in calculated positions. The structure of 1. $\left(\mathrm{CH}_{3} \mathrm{CH}_{2}\right)_{2} \mathrm{O}$ exhibits a disordered diethyl ether molecule in the asymmetric unit which is refined between three positions. The structure of $\mathbf{4}$ exhibits a disordered coordinated DMF molecule which is refined between two positions. All presented ORTEP plots show probability ellipsoids of $50 \%{ }^{44}$

\section{Conclusions}

The successful isolation of a series of uranyl complexes with the maleonitrile containing ligand (salmnt ${ }^{\left(\mathrm{Et}_{2} \mathrm{~N}\right)_{2}}$ ) ${ }^{2-}$ allows us to explore further the redox behaviour of uranium coordinated to redox active ligands. The highly conjugated nature of the $\left(\mathrm{salmnt}^{\left(\mathrm{Et}_{2} \mathrm{~N}\right)_{2}}\right)^{2-}$ ligand provides a very absorbing chromophore in the visible region of the spectrum, and the luminescence lifetimes of these complexes indicate ligand-based emission behaviour. Single crystal X-ray diffraction studies of all the uranyl complexes presented demon- strate distorted coordination of the (salmnt $\left.{ }^{\left(\mathrm{Et}_{2} \mathrm{~N}_{2}\right.}\right)^{2-}$ ligand about the uranyl equatorial plane predominantly due to the rigid nature of the maleonitrile unit. This results in vibrational behaviour where the $v_{1}$ uranyl stretch is observed in the infrared spectrum due to the lowering of the complex symmetry. This uranyl stretching mode is observed in the Raman spectra of complexes 1-5, but with signals of extremely weak intensity. The minimal change in the polarisability of the $\mathrm{U}=\mathrm{O}$ bond that occurs with the $v_{1}$ $(\mathrm{O}=\mathrm{U}=\mathrm{O})$ stretch for complexes $\mathbf{1 - 5}$ is probably caused by the nature of the distorted coordination of the (salmnt $\left.{ }^{\left(\mathrm{Et}_{2} \mathrm{~N}_{2}\right.}\right)^{2-}$ ligand about the uranyl equatorial plane, and not just the lowering of the complex symmetry. Electrochemical studies of the complexes 2-5 in DCM show reversible redox processes, which are most likely uranyl-based, at some of the most negative potentials ever reported for the $\left\{\mathrm{UO}_{2}\right\}^{2+} /\left\{\mathrm{UO}_{2}\right\}^{+}$couple. This is likely to be due to strong $\pi$-donation from the (salmnt $\left.{ }^{\left(\mathrm{E}_{2} \mathrm{~N}_{2}\right.}\right)^{2-}$ ligand and the exact nature of this bonding will be explored further using theoretical calculations. The possibility that the reduced complexes may display non-innocent behaviour will be investigated. The uranyl complexes also exhibit redox features that can be attributed to ligand-based oxidations, possibly giving radical and/or quinone containing complexes. The exact nature of both oxidative and reductive processes will be probed further using EPR and UVvisible absorption spectroelectrochemical methods. Further work will also investigate the properties of $\left\{\mathrm{UO}_{2}\right\}^{+}$and transuranic (i.e. $\left.\left\{\mathrm{NpO}_{2}\right\}^{2+/},\left\{\mathrm{PuO}_{2}\right\}^{2+}\right)$ complexes with this ligand, and the exploitation of the peripheral cyano groups for the possible formation of multimetallic arrays and the synthesis of larger ligand systems. 


\section{Acknowledgements}

We thank the Nuclear Decommissioning Authority (UK) for funding a research fellowship (CAS), EPSRC for funding a DTA studentship (DSR) and Prof. David Collison for helpful discussions.

\section{Notes and references}

1 The Chemistry of the Actinide Elements, ed. J. J. Katz, G. T. Seaborg, and L. R. Morss, Chapman and Hall, London, 2nd edn, 1986, vol. 1.

2 G. H. John, I. May, C. A. Sharrad, A. D. Sutton, D. Collison, M. Helliwell and M. J. Sarsfield, Inorg. Chem., 2005, 44, 7606; H. D. Burrows and T. J. Kemp, Chem. Soc. Rev., 1974, 3, 139; A. W. Adamson, W. L. Waltz, E. Zinato, D. W. Watts, P. D. Fleishauer and R. D. Lindholm, Chem. Rev., 1968, 68, 541.

3 A. Ekstrom, Inorg. Chem., 1974, 13, 2237.

4 L. Natrajan, F. Burdet, J. Pécaut and M. Mazzanti, J. Am. Chem. Soc., 2006, 128, 7152 .

5 K. Mizuoka, S. -Y. Kim, M. Hasegawa, T. Hoshi, G. Uchiyama and Y. Ikeda, Inorg. Chem., 2003, 42, 1031; K. Mizuoka, S. Tsushima, M. Hasegawa, T. Hoshi and Y. Ikeda, Inorg. Chem., 2005, 44, 6211; K. Mizuoka and Y. Ikeda, Radiochim. Acta, 2004, 92, 631.

6 S.-Y. Kim, H. Tomiyasu and Y. Ikeda, J. Nucl. Sci. Technol., 2002, 39, 160.

7 S.-H. Lee, K. Mizuguchi, H. Tomiyasu and Y. Ikeda, J. Nucl. Sci. Technol., 1996, 33, 190; K. Mizuguchi, S.-H. Lee, Y. Ikeda and H. Tomiyasu, J. Alloys Compd., 1998, 271-273, 163.

8 P. L. Arnold, D. Patel, C. Wilson and J. B. Love, Nature, 2008, 451, 315; J.-C. Berthet, G. Siffredi, P. Thuery and M. Ephritikhine, Dalton Trans., 2009, 3478.

9 P. Horeglad, G. Nocton, Y. Filinchuk, J. Pécaut and M Mazzanti, Chem. Commun., 2009, 1843; V. Mougel, P. Horeglad, G. Nocton, J. Pécaut and M. Mazzanti, Angew. Chem., Int. Ed., 2009, 48, 8477; G. Nocton, P. Horeglad, V. Vetere, J. Pécaut, L. Dubois, P. Maldivi, N. M. Edelstein and M. Mazzanti, J. Am. Chem. Soc., 2010, 132, 495.

10 T. W. Hayton and G. Wu, Inorg. Chem., 2009, 48, 3065; T. W. Hayton and G. Wu, Inorg. Chem., 2008, 47, 7415.

11 S. R. Sofen, S. R. Cooper and K. N. Raymond, Inorg. Chem., 1979, 18, 1611.

12 M. J. Kappel, H. Nitsche and K. N. Raymond, Inorg. Chem., 1985, 24, 605.

13 P. W. Durbin, B. Kullgren, S. N. Ebbe, J. Xu and K. N. Raymond, Health Phys., 2000, 78, 511 .

14 S. J. Kraft, P. E. Fanwick and S. C. Bart, Inorg. Chem., 2010, 49, 1103; G. S. Girolami, S. N. Milam and K. S. Suslick, J. Am. Chem. Soc., 1988, 110, 2011; O. P. Lam, C. Anthon, F. W. Heinemann, J. M. O'Connor and K. Meyer, J. Am. Chem. Soc., 2008, 130, 6567; O. P. Lam, P. L. Feng, F. W. Heinemann, J. M. O'Connor and K. Meyer, J. Am. Chem. Soc., 2008, 130, 2806.

15 J. W. Lauher and J. A. Ibers, Inorg. Chem., 1975, 14, 640; T.-S. Hwang and Y. Wang, J. Phys. Chem. A, 1998, 102, 3726; W. E. Geiger Jr. and F. C. Senftleber, J. Am. Chem. Soc., 1975, 97, 5018; F. C. Senftleber and W. E. Geiger Jr., Inorg. Chem., 1978, 17, 3615.

16 M. J. MacLachlan, M. K. Park and L. K. Thompson, Inorg. Chem., $1996, \mathbf{3 5}, 5492$.

17 H. J. Drexler, H. Reinke and H. J. Holdt, Chem. Ber., 1996, 129, 807; J. W. Sibert, S. J. Lange, C. Stern, B. M. Hoffmann and A. G. M. Barrett, J. Chem. Soc., Chem. Commun., 1994, 1751-1752.

18 M. Cametti, M. Nissinen, A. D. Cort, L. Mandolini and K. Rissanen, J. Am. Chem. Soc., 2005, 127, 3831; D. M. Rudkevich, W. Verboom,
Z. Brzozka, M. J. Palys, W. P. R. V. Stauthamer, G. J. van Hummel, S. M. Franken, S. Harkema, J. F. J. Engbersen and D. N. Reinhoudt, J. Am. Chem. Soc., 1994, 116, 4341; J. L. Sessler, P. J. Melfi and G. Dan Pantos, Coord. Chem. Rev., 2006, 250, 816.

19 I. Ledoux and J. Zyss, Pure Appl. Opt., 1996, 5, 603; P. G. Lacroix, S. Di Bella and I. Ledoux, Chem. Mater., 1996, 8, 541.

20 P. Wang, Z. Hong, Z. Xie, S. Tong, O. Wong, C. Lee, N. Wong, L. Hung and S. Lee, Chem. Commun., 2003, 1664.

21 K. Takao and Y. Ikeda, Inorg. Chem., 2007, 46, 1550.

22 L. Cattalini, S. Degetto, M. Vidali and P. A. Vigato, Inorg. Chim. Acta, 1972, 6, 173.

23 E. M. Nour, A. A. Taha and I. S. Alnaimi, Inorg. Chim. Acta, 1988, $141,139$.

24 L. Sacconi, G. Caroti and P. Paoletti, J. Chem. Soc., 1958, 4257.

25 H. Kunkely and A. Vogler, Z. Naturforsch., 2002, 57b, 301; P. Bandoli, D. A. Clemente, U. Croatto, M. Vidali and P. A. Vigato, J. Chem. Soc. $D, 1971,1330$.

26 H. Kunkely and A. Vogler, Inorg. Chim. Acta, 2001, 321, 171.

27 R. G. Denning, J. Phys. Chem. A, 2007, 111, 4125.

28 G. Bandoli, D. A. Clemente, U. Croatto, M. Vidali and P. A Vigato, J. Chem. Soc., Dalton Trans., 1973, 2331.

29 V. M. Leovac, E. Z. Ivegeš, N. Galešić and D. Horvatić, Inorg. Chim. Acta, 1989, 162, 277; A. R. van Doorn, R. Schaafstra, M. Bos, S. Harkema, J. van Eerden, W. Verboom and D. N. Reinhouldt, J. Org. Chem., 1991, 56, 6083; A. E. Vaughn, D. B. Bassil, C. L. Barnes, S. A. Tucker and P. B. Duval, J. Am. Chem. Soc., 2006, 128, 10656.

30 R. D. Rogers, L. K. Kurihara and M. M. Benning, J. Inclusion Phenom., 1987, 5, 645; L. Deshayes, N. Keller, M. Lance, M. Nierlich and J.-D. Vigner, Acta Crystallogr., Sect. C: Cryst. Struct. Commun., 1994, 50, 1541.

31 A. M. Reichwein, W. Verboom, S. Harkema, A. L. Spek and D. N. Reinhoudt, J. Chem. Soc., Perkin Trans. 2, 1994, 1167; M. E. Amato, F. P. Ballistreri, A. Pappalardo, G. A. Tomaselli, R. M. Toscano and D. J. Williams, Eur. J. Org. Chem., 2005, 3562; M. Bassetti, A. Calenne, L. Mastrofrancesco, M. Salamone, G. Bocelli, A. Cantoni and A. Musatti, Eur. J. Inorg. Chem., 2006, 914.

32 N. W. Alcock, D. J. Flander and D. Brown, J. Chem. Soc., Dalton Trans., 1984, 679; C. C. Gatto, E. S. Lang, A. Kupfer, A. Hagenbach, D. Willie and U. Abram, Z. Anorg. Allg. Chem., 2004, 630, 735.

33 D. J. Evans, P. C. Junk and M. K. Smith, Polyhedron, 2002, 21, 2421; M. S. Bharara, S. A. Tonks and A. E. V. Gorden, Chem. Commun., 2007, 4006.

34 F. J. Arnáiz, M. J. Miranda, R. Aguado, J. Mahía and M. A. Maestro, Polyhedron, 2002, 21, 2755; M. J. Sarsfield, A. D. Sutton, I. May, G. H. John, C. Sharrad and M. Helliwell, Chem. Commun., 2004, 2320.

35 C. G. Pierpont and R. M. Buchanan, Coord. Chem. Rev., 1981, 38, 45.

36 G. Nocton, P. Horeglad, V. Vetere, J. Pécaut, L. Dubois, P. Maldivi, N. M. Edelstein and M. Mazzanti, J. Am. Chem. Soc., 2010, 132, 495.

37 D. L. Clark, S. D. Conradson, R. J. Donohoe, D. W. Keogh, D. E. Morris, P. D. Palmer, R. D. Rogers and C. D. Tait, Inorg. Chem., 1999, 38, 1456.

38 J. P. Austin, M. Sundararajan, M. A. Vincent and I. H. Hillier, Dalton Trans., 2009, 5902.

39 D. E. Morris, Inorg. Chem., 2002, 41, 3542.

40 M. S. Bharara, S. A. Tonks and A. E. V. Gorden, Chem. Commun., 2007, 4006.

41 G. M. Sheldrick, Acta Crystallogr., Sect. A: Found. Crystallogr., 1990, 46, 467.

42 A. Altomare, G. Cascorano, C. Giacovazzo and A. Gualardi, J. Appl. Crystallogr., 1993, 26, 343.

43 G. M. Sheldrick, SHELXL-97, Program for refinement of crystal structures, University of Göttingen, Germany, 1997.

44 L. J. Farrugia, J. Appl. Crystallogr., 1997, 30, 565. 